\title{
A DINÂMICA DA RECENTE EXPANSÃO DO SETOR SUCROENERGÉTICO NO TRIÂNGULO MINEIRO/ALTO PARANAÍBA: DA INTERNACIONALIZAÇÃO À FORMAÇÃO DOS GRANDES GRUPOS ${ }^{1}$
}

\author{
Henrique Faria dos Santos ${ }^{2}$
}

\begin{abstract}
Resumo
O presente artigo objetiva analisar a dinâmica da recente expansão do setor sucroenergético no Triângulo Mineiro/Alto Paranaíba, sob a ótica da atual organização corporativa da atividade no território brasileiro, isto é, da formação dos grandes grupos e da internacionalização das operações. Sobretudo a partir dos anos 2000, o setor passou por grandes mudanças que reorganizou 0 capital das empresas e consolidou novos investimentos nos mercados do açúcar, etanol e bioeletricidade. A sistematização de dados e informações, obtidas mediante revisão bibliográfica, pesquisa estatístico-documental e trabalhos de campo, puderam mostrar que a área de estudo passou por um forte processo de expansão do setor sucroenergético nos últimos anos. Isto ocorreu muito em função dos investimentos de grandes grupos, sendo alguns estrangeiros, na fusão ou aquisição de unidades agroindustriais existentes e construção de outras, elevando, assim, a capacidade produtiva e as exportações.
\end{abstract}

Palavras-chave: setor sucroenergético; internacionalização; concentração de capital; Triângulo Mineiro/Alto Paranaíba.

\section{THE DINAMICS OF THE RECENT EXPANSION OF THE SUGARCANE INDUSTRY IN THE TRIÂNGULO MINEIRO/ALTO PARANAÍBA: FROM INTERNATIONALIZATION TO THE FORMATION OF THE GREAT GROUPS}

\begin{abstract}
This article aims at to analyze the dynamics of the recent expansion of the sugarcane industry in the Triângulo Mineiro/Alto Paranaíba, under the perspective of the current corporate organization this activity in the Brazilian territory, that is, of the formation of the great groups and of the internationalization of the operations. Especially after the 2000's, the sector has been major changes that it reorganized the capital of the companies and it consolidated new investments in the sugar, ethanol and bioelectricity markets. The systemization of data and information, obtained through bibliographical
\end{abstract}

\footnotetext{
${ }^{1}$ Artigo produzido a partir da dissertação de mestrado, com apoio financeiro da FAPESP.

${ }^{2}$ Universidade Estadual de Campinas (UNICAMP). E-mail: Livehenriquefariasantos@hotmail.com

Estudos Geográficos, Rio Claro, 15(1): 106-132, jan./jun. 2017 (ISSN 1678-698X)

http://www.periodicos.rc.biblioteca.unesp.br/index.php/estgeo
} 
revision, statistical-documental research and field works allows us to conclude that the study area went by a fort process of expansion of the sugarcane industry in the last years. This was largely due to the investments of great groups, being some foreigners, in fusion or acquisition of agroindustriais units existents and build of others, increasing the production capacity and the exports.

Keywords: sugarcane industry; internationalization; concentration of capital; Triângulo Mineiro/Alto Paranaíba.

\section{INTRODUÇÃO}

Desde a década de 1990, o setor sucroenergético brasileiro vem passando por grandes mudanças de ordens técnica e político-normativa, muito em decorrência do contexto de alinhamento das políticas estatais ao ideário neoliberal (HARVEY, 2011) e da maior abertura da economia nacional aos desígnios da globalização (HIRST; THOMPSON, 1998). Somado a isso, a expansão do meio técnico-científico-informacional no território (SANTOS, 2008) e a constituição de uma agricultura cada vez mais científica e globalizada (SANTOS, 2010) levou diversas atividades do agronegócio à intensa modernização e ao controle por grandes grupos nacionais e estrangeiros altamente capitalizados. Desta forma assiste-se, no seio da organização da agricultura nacional, um processo gradativo de desregulamentação estatal e de reestruturação produtiva de cunho corporativista que tenderam à internacionalização cada vez maior das atividades.

No caso do setor sucroenergético, foi sobretudo a partir da década de 2000 , com as novas possibilidades de investimento e rentabilidade no mercado de açúcar, etanol e, recentemente, da bioeletricidade, que vários grupos econômicos, especialmente transnacionais, entraram no ramo, mediante Fusões, Aquisições e/ou Associações (F\&A). A maior presença desses agentes, normalmente com alto poder financeiro, possibilitou a elevação dos investimentos em Pesquisa e Desenvolvimento (P\&D) e a difusão de várias inovações científico-tecnológicas no setor, capazes de adaptar produtos e processos a diferentes especificidades técnicas locais, sobretudo no que diz respeito aos aspectos agrícolas (novas variedades de cana-de-açúcar), e induziu a incorporação/exploração de novas áreas para a expansão sucroenergética, como as regiões de domínio morfoclimático do Cerrado (AB'SÁBER, 2003). 
É neste contexto que ocorreu a recente expansão canavieira na mesorregião Triângulo Mineiro/Alto Paranaíba. Além da existência de vários fatores geográficos de competitividade regional do setor sucroenergético que atraíram novas unidades agroindustriais sucroenergéticas (UAS), conforme constatado por Santos (2017), a região teve forte processo de modernização e concentração de capital nas atividades agrícolas e agroindustriais da cana-deaçúcar, consolidando a formação recente de grandes grupos. A maior presença de empresas com capital majoritariamente estrangeiro nas UAS, a presença ou proximidade de nós logísticos (BRAGA; CASTILLO, 2013), como o Terminal Terrestre da Logum e o Terminal Integrador da VLI em Uberaba/MG, o Porto Seco do Cerrado em Uberlândia/MG e os terminais de carga de açúcar localizados no oeste do estado de São Paulo, que resultaram no aumento das exportações de açúcar e etanol, evidenciam um processo de internacionalização do setor sucroenergético na região.

Assim, o objetivo do presente artigo é o de analisar a dinâmica da recente expansão do setor sucroenergético no Triângulo Mineiro/Alto Paranaíba, sob a ótica da atual organização corporativa da atividade no território brasileiro. Para tanto, a metodologia adotada na pesquisa foi a consecução de três etapas interdependentes: 1) levantamento e revisão bibliográfica (livros, artigos, teses, dissertações e reportagens) sobre 0 processo recente de expansão e consolidação do setor sucroenergético no Brasil e no Triângulo Mineiro/Alto Paranaíba; 2) levantamento documentalestatístico para obtenção de dados e informações secundárias acerca da área de cultivo, produção e rendimento da cana-de-açúcar (Instituto Brasileiro de Geografia e Estatística - IBGE, CANASAT/INPE), da produção, consumo e exportação de açúcar e etanol (União da Indústria de Cana-de-Açúcar UNICA, Ministério da Agricultura, Pecuária e Abastecimento - MAPA, Ministério de Desenvolvimento, Indústria e Comércio Exterior - MDIC), do número de UAS, da dinâmica produtiva e dos grupos controladores (Portal NovaCana, Infocana e Anuário da Cana); 3) trabalhos de campo na região para execução de entrevistas, visitas técnicas e observações empíricas em UAS, produtores rurais de cana, órgãos públicos (secretarias municipais, empresas de assistência técnica), instituições de representação da classe trabalhadora (Federação dos Trabalhadores da Agricultura do Estado de Minas Gerais FETAEMG) e patronal (Associação das Indústrias Sucroenergéticas de Minas Gerais - SIAMIG).

$\mathrm{O}$ artigo está divido em duas partes principais. A primeira faz uma breve contextualização sobre a organização atual do setor sucroenergético no Brasil, abordando os principais fatores que levaram ao último ciclo de crescimento, os aspectos da internacionalização e os grupos econômicos envolvidos. Já a segunda parte, visa analisar o processo de expansão do setor no Triângulo Mineiro/Alto Paranaíba, elencando os principais grupos que atuam hoje nas atividades de processamento da cana-de-açúcar, e apresentando alguns dados que demonstram a ampliação da produção agrícola e das exportações na região. 


\section{A EMERGÊNCIA DOS VEÍCULOS FLEXFUEL, INTERNACIONALIZAÇÃO E EXPANSÃO DO SETOR SUCROENERGÉTICO NO BRASIL}

O Brasil vivenciou um forte ciclo de crescimento do setor sucroenergético no início da década de 2000, devido a vários fatores dos mercados interno e externo. Um dos principais fatores foi a introdução dos veículos flexfuel (movidos tanto a gasolina quanto a etanol, em qualquer proporção) no mercado automobilístico. A possibilidade dos consumidores escolherem o tipo de combustível para abastecer os seus veículos dinamizou o mercado de combustíveis, favorecendo muito o setor sucroalcooleiro nos momentos de maior competitividade dos preços do etanol em relação ao seu principal concorrente, a gasolina. Segundo a Associação Nacional dos Fabricantes de Veículos Automotores (ANFAVEA, 2015), entre 2003 e 20150 número de veículos flexfuel licenciados no Brasil passou de 48.178 para mais de 2,1 milhões de unidades, (chegando a 3,8 milhões em 2012) e a participação deste tipo de veículo no total dos licenciamentos elevou-se de $3,5 \%$ para quase $86 \%$. Além disso, o aumento do consumo de gasolina no país, que passou de 22,6 para 41,1 bilhões de litros entre 2000 e 2015, fez aumentar proporcionalmente o consumo de etanol anidro (de 5,7 para 10,9 bilhões de litros), hoje com uma taxa de mistura à gasolina estabelecido em 27\% (ANP, 2015).

Com isso, o consumo interno de etanol aumentou extraordinariamente, tornando sua produção uma atividade muito lucrativa às empresas envolvidas na agroindústria canavieira. De acordo com os dados da UNICADATA (2017), o consumo total de etanol quase triplicou no país entre 2000 e 2015, passando de 10,3 para 28,7 bilhões de litros. Em relação ao açúcar, os dados do MAPA (2015) mostram que o consumo interno se manteve estável nos últimos anos, variando em torno de 10 a 13 milhões de toneladas.

Outros fatores também foram essenciais para a retomada do crescimento da atividade canavieira: i) a elevação sistemática dos preços internacionais do petróleo (garantindo maior viabilidade econômica aos preços do etanol combustível em relação à gasolina) e do açúcar; ii) perspectivas do aumento da demanda externa de etanol anidro em vários países, devido aos mandatos de mistura deste combustível à gasolina, objetivando cumprir parte dos acordos definidos no Protocolo de Kyoto para a redução das emissões dos Gases de Efeito Estufa (GEE), além de aumentar a segurança energética (REN21, 2015); iii) expectativa de commoditização do etanol; iv) o aumento da produção de bioeletricidade a partir da queima do bagaço da cana e de outros resíduos agrícolas e florestais, com a possibilidade de realizar a comercialização do excedente elétrico para o Sistema Interligado Nacional de Energia Elétrica (SIN) (CGEE, 2009; LEMOS et al., 2015). Destarte, novas UAS foram projetadas e construídas (greenfields) e outras ampliadas e modernizadas em curto período de tempo (brownfields), face a esse repentino aquecimento do mercado. Segundo a EPE (2015), 138 novas unidades foram criadas entre 2005 e 2013 no Brasil, em parte com capital estrangeiro.

A área plantada com cana-de-açúcar aumentou de 4,8 para 10,1 milhões de hectares e a quantidade produzida de 326 para 748 milhões de toneladas, Estudos Geográficos, Rio Claro, 15(1): 106-132, jan./jun. 2017 (ISSN 1678-698X) http://www.periodicos.rc.biblioteca.unesp.br/index.php/estgeo 
enquanto que o rendimento médio teve pouca expressão, de 67,8 para 74,1 t/ha (tabela 1). A produção dos derivados industriais da cana também teve grande aumento. Entre as safras 2000/2001 e 2015/2016, a produção de açúcar saltou de 16,1 para 33,9 mil toneladas e a de etanol passou de 10,5 para 30,3 mil $\mathrm{m}^{3}$ (UNICADATA, 2017). Já a bioeletricidade sucroenergética ofertada no SIN, elevou-se de 0,8 para 20,4 TWh representando, hoje, 4,3\% da matriz elétrica nacional (UNICA, 2016). Em termos de exportações, o etanol teve crescimento tímido entre 2000 e 2008 (de 229 milhões para 5,1 bilhões de litros) e decrescimento entre 2009 e 2015 (3,3 para 1,8 bilhões de litros), ao contrário do que ocorreu com o açúcar, cujo comércio teve um crescimento de $269 \%$ entre 2000 e 2015, ou seja, de 6,5 para 24 milhões de toneladas exportadas (MDIC, 2017).

Tabela 1 - Brasil: área plantada, área colhida, quantidade produzida e rendimento médio da produção de cana-de-açúcar, 2000-2015 (anos selecionados)

\begin{tabular}{ccccc}
\hline Anos & $\begin{array}{c}\text { Área plantada } \\
\text { (hectares) }\end{array}$ & $\begin{array}{c}\text { Área colhida } \\
\text { (hectares) }\end{array}$ & $\begin{array}{c}\text { Quantidade } \\
\text { produzida } \\
\text { (toneladas) }\end{array}$ & $\begin{array}{c}\text { Rendimento } \\
\text { médio (ton./ha) }\end{array}$ \\
\hline 2000 & 4.879 .841 & 4.804 .511 & 326.121 .011 & 67,8 \\
2005 & 5.815 .151 & 5.805 .518 & 422.956 .646 & 72,5 \\
2010 & 9.164 .756 & 9.076 .706 & 717.463 .793 & 79,0 \\
2015 & 10.161 .622 & 10.093 .171 & 748.636 .167 & 74,1 \\
\hline
\end{tabular}

Fonte: Produção Agrícola Municipal - PAM (IBGE, 2016). Organização: autor

O grande crescimento do setor sucroenergético atraiu o interesse de diversas corporações transnacionais e fundos de investimentos estrangeiros que aos poucos foram realizando fusões, aquisições e associações (jointventures) com várias usinas/destilarias e distribuidoras brasileiras (MACÉDO, 2011; FAÇANHA, 2012), marcando um processo de internacionalização (PINTO, 2011) e centralização de capital no setor (SPADOTTO, 2015; PITTA, 2016). Segundo o JornalCana (2015), a participação dessas empresas no total da moagem de cana-de-açúcar no país subiu de 16\% na safra 2009/2010 para $24 \%$ na safra 2014/2015. Já o NOVACANA (2013b) afirma que a participação estrangeira na produção brasileira de açúcar e etanol aumentou de $3 \% \mathrm{em}$ 2006 para 33\% em 2013. Na safra 2015/2016, dentre os 15 maiores grupos do setor sucroenergético, 6 eram de capital majoritariamente estrangeiro (Raízen ${ }^{3}$, Biosev, Bunge, Tereos, CofcoAgri e Renuka), participando em $23 \%$ da moagem de cana, $17,2 \%$ da produção de etanol e $29,8 \%$ da produção de açúcar no país (tabela 2). Lemos et al. (2016) afirmam que a internacionalização do setor não ocorreu apenas no sistema produtivo, mas também na distribuição e P\&D.

Uma das características que diferenciam o perfil recente do setor do seu padrão histórico é justamente a relativa

\footnotetext{
${ }^{3}$ Embora o caso da Raízen seja considerada uma propriedade mista (50\% da Cosan e 50\% da Royal Dutch Shell), o contrato prevê que a Shell poderá comprar até $100 \%$ das ações da Cosan até 2025 . Mais informações podem ser consultadas em: ONAGA, M. Adeus, etanol, diz Rubens Ometto. Revista Exame, 2012. Disponível em:<http://exame.abril.com.br/revistaexame/edicoes/1016/noticias/adeusetanol-dizrubens-ometto>. Acesso em: Out/2015.

Estudos Geográficos, Rio Claro, 15(1): 106-132, jan./jun. 2017 (ISSN 1678—698X)

http://www.periodicos.rc.biblioteca.unesp.br/index.php/estgeo
} 
A dinâmica da recente expansão do setor sucroenergético...

internacionalização da estrutura de capital das empresas, com fusões e aquisições de organizações e plantas que não atingem apenas o sistema produtivo, mas também 0 de distribuição e $P \& D$, revelando novos negócios e novas redes de inovação resultantes da associação entre empresas dos vários elos da cadeia, acompanhada por uma participação de capitais industriais e financeiros globais (LEMOS et al., 2015, p. 17).

Tabela 2 - Controle acionário, número de UAS, capacidade de moagem, moagem de cana-de-açúcar, produção dos derivados (etanol, açúcar e bioeletricidade) e participação nacional dos quinze maiores grupos do setor sucroenergético, safra 2015/2016

\begin{tabular}{|c|c|c|c|c|c|c|c|c|c|c|}
\hline \multicolumn{4}{|c|}{ Dados dos grupos } & \multicolumn{7}{|c|}{ Produção na safra 2015/2016 } \\
\hline Grupo & $\begin{array}{c}\text { Controle } \\
\text { acionário }\end{array}$ & $\begin{array}{l}\text { N. de } \\
\text { UAS }\end{array}$ & $\begin{array}{l}\text { Capacidade } \\
\text { de moagem } \\
\text { (milhões }^{(1)} \\
\text { t/safra) }^{(1)}\end{array}$ & $\begin{array}{l}\text { Moagem } \\
\text { (milhões }^{(2)} \\
\text { de t) }\end{array}$ & $\underset{(3)}{\text { Part. }}(\%)$ & $\begin{array}{c}\text { Etanol } \\
\left(\mathrm{mil} \mathrm{m}^{3}\right)^{(2)}\end{array}$ & $\underset{(3)}{\text { Part. }}(\%)$ & $\begin{array}{l}\text { Açúcar } \\
\text { (mil t) }^{(2)}\end{array}$ & $\underset{(3)}{\operatorname{Part.}(\%)}$ & $\begin{array}{c}\text { Bioeletricidade } \\
\text { comercializada } \\
(\mathrm{MW} / \mathrm{h})^{(2)}\end{array}$ \\
\hline & Brasil// & & & & & & & & & \\
\hline Raízen & Holanda & 24 & 68,0 & 62,7 & 9,4 & $2.073,9$ & 6,9 & $4.177,7$ & 12,3 & 2.870 .000 \\
\hline Biosev (LDC) & França & 11 & 36,4 & 30,9 & 4,6 & $1.239,0$ & 4,1 & $1.705,0$ & 5,0 & 929.000 \\
\hline Odebrecht & Brasil & 9 & 36,0 & 29,2 & 4,4 & $1.943,4$ & 6,4 & 455,3 & 1,3 & 2.972 .685 \\
\hline São Martinho & Brasil & 4 & 23,0 & 22,3 & 3,4 & 943,7 & 3,1 & $1.229,7$ & 3,6 & 907.780 \\
\hline Bunge & EUA & 8 & 21,0 & 21,0 & 3,1 & $500,0^{*}$ & 1,7 & $1.500,0^{*}$ & 4,4 & 570.043 \\
\hline Tereos & França & 7 & 23,0 & 19,6 & 2,9 & 678,0 & 2,2 & $1.444,0$ & 4,3 & 1.400 .000 \\
\hline Santa Terezinha & Brasil & 9 & 22,0 & 17,9 & 2,7 & 445,9 & 1,5 & $1.689,4$ & 5,0 & 380.000 \\
\hline Coruripe & Brasil & 5 & 13,6 & 14,1 & 2,1 & 483,4 & 1,6 & 740,4 & 2,2 & 411.168 \\
\hline Lincon Junqueira & Brasil & 5 & 16,0 & 13,5 & 2,0 & 352,2 & 1,2 & $1.165,5$ & 3,4 & 174.700 \\
\hline CofcoAgri & China & 4 & 15,0 & 11,0 & 1,6 & 280,0 & 0,9 & 900,0 & 2,7 & N.I. \\
\hline Zilor & Brasil & 3 & 12,0 & 10,8 & 1,6 & 502,5 & 1,7 & 494,3 & 1,5 & 547.940 \\
\hline Clealco & Brasil & 3 & 11,0 & 9,9 & 1,5 & $295,1^{\star *}$ & - & $626,6^{* *}$ & - & $108.807^{\star *}$ \\
\hline Renuka do Brasil & Índia & 4 & 10,0 & 9,8 & 1,5 & 440,0 & 1,5 & 366,8 & 1,1 & 302.904 \\
\hline Moreno & Brasil & 3 & 11,0 & 9,5 & 1,4 & 517,5 & 1,7 & 334,1 & 1,0 & N.I. \\
\hline Delta Sucroenergia & Brasil & 3 & 10,0 & 9,1 & 1,4 & 289,5 & 1,0 & 702,2 & 2,1 & 147.197 \\
\hline $\begin{array}{r}\text { Brasil } \\
\end{array}$ & & 379 & - & 666,8 & 100,0 & $30.232,0$ & 100,0 & $33.837,0$ & 100,0 & - \\
\hline
\end{tabular}

Outros aspectos da internacionalização do setor sucroenergético são o aumento das exportações e a comercialização do açúcar e do etanol em mercados cada vez mais distantes e diversificados. Para conquistar tais mercados (nações e blocos econômicos, como a União Europeia, EUA e Japão), exigentes em relação a determinadas qualidades e custos, as certificações internacionais têm sido uma porta de entrada para que muitas empresas do setor acessem novas oportunidades de negócio. De acordo com Makiya (2015), as certificações têm um papel central na adoção de critérios técnicos e de responsabilidade socioambiental, emergindo como marcos regulatórios essenciais para inovações institucionais e tecnológicas no setor sucroenergético. A autora destaca ainda que, por incluir uma série de princípios, critérios, padrões e indicadores, tais registros servem como instrumento de propriedade intelectual que justamente diferencia e permite apropriação de valor, qualificando, portanto, o produto a ser comercializado internacionalmente.

Estudos Geográficos, Rio Claro, 15(1): 106-132, jan./jun. 2017 (ISSN 1678-698X) http://www.periodicos.rc.biblioteca.unesp.br/index.php/estgeo 
A BONSUCRO 4 é hoje a principal certificação do setor sucroenergético e tem como principal objetivo garantir uma padronização global da produção. Xavier (2012) comenta que as certificações corroboram fortemente com o processo de commoditização do etanol, pois considerando que um dos principais impeditivos com relação à sua conversão é garantir um padrão global de produção, a elaboração de sistemas como o BONSUCRO objetiva, justamente, direcionar e acelerar o cumprimento dessa meta. Até 2016, aproximadamente $4 \%$ da área e produção mundial de cana-de-açúcar já haviam sido certificadas e 129 empresas brasileiras possuíam registro, incluindo grandes grupos do setor, como a Raízen, Copersucar, Biosev, São Martinho, Odebrecht Agroindustrial, Tereos International, Tércio Wanderley, Bunge, Cargill, CofcoAgri, Adecoagro, Alvean Sugar, Wilmar International, Zilor, Lincon Junqueira e CMAA (BONSUCRO, 2016).

Contudo, a internacionalização é responsável por outro processo em andamento no setor sucroenergético: o de oligopolização da produção e comercialização do açúcar e do etanol. Com as crises econômica e financeira internacionais de 2007-2008, os movimentos de internacionalização, concentração e centralização do capital no setor tornaram-se mais evidentes, corroborando na formação de grandes grupos no setor (MENDONÇA; PITTA; XAVIER, 2012).

Segundo dados da KPMG (2016), entre os anos 2000 e 2015 houve 166 operações de F\&A no setor sucroenergético, sendo que mais da metade (90 operações) ocorreram a partir de 2008. Essas operações foram realizadas, em boa parte, por corporações transnacionais, que passaram a investir pesadamente no setor sobretudo a partir dos anos 2000. O aumento do número de $F \& A$ e o fechamento de unidades agroindustriais indicam movimentos de centralização de capital no setor (SPADOTTO, 2015; PITTA, 2016), o que refletiu diretamente na concentração da produção e comercialização dos derivados da cana-de-açúcar. Segundo Macêdo (2011), na safra 2004/2005, os dez maiores grupos sucroenergéticos respondiam por $23,8 \%$ dos 386,09 milhões de toneladas de cana moída no Brasil e por 30,9\% e $26,3 \%$ das produções totais de açúcar e etanol, respectivamente. Na safra $2011 / 2012$, estes responderam por $27 \%$ do total da cana moída, $29 \%$ da produção de açúcar e $24 \%$ da produção de etanol (BARBOSA, 2013). Já na safra $2015 / 2016$, foram responsáveis por aproximadamente $36 \%$ da moagem de cana, $44 \%$ da produção de açúcar e $29 \%$ da produção de etanol (INFOCANA, 2017).

Em relação à distribuição/comercialização do açúcar e do etanol, observa-se o predomínio de grandes tradings nacionais e estrangeiras que, inclusive, participam diretamente na produção dos mesmos, como Copersucar, LDC, Bunge, Tereos, CoofcoAgri, Sojitz Corporation, Indofood, etc. Se considerarmos, por exemplo, a participação dos grupos Copersucar/Alvean e da Raízen/Raw (que se associaram e, sozinhas, podem concentrar mais da metade das exportações brasileiras de açúcar) e de mais outras três grandes tradings que atuam no setor sucroenergético brasileiro atualmente - a Louis Dreyfus Companies - LDC (que detém mais de $70 \%$ das ações da Biosev,

\footnotetext{
${ }^{4}$ O sistema BONSUCRO é uma iniciativa global, multistakeholder e sem fins lucrativos, cujo objetivo (em seu discurso) é dedicar-se a reduzir os impactos ambientais e sociais da produção de cana-de-açúcar enquanto reconhece a necessidade de viabilidade econômica. Aplica-se em todo o mundo a qualquer unidade de processamento de cana-de-açúcar e sua área de fornecimento.

Estudos Geográficos, Rio Claro, 15(1): 106-132, jan./jun. 2017 (ISSN 1678-698X)

http://www.periodicos.rc.biblioteca.unesp.br/index.php/estgeo
} 
segunda maior processadora global de cana-de-açúcar), a Tereos (que detém $60 \%$ do Grupo Guarani, quarto maior produtor do setor) e a Bunge (quinto maior grupo do setor, com 8 UAS) - é evidente que tanto a produção quanto a distribuição/comercialização do etanol e do açúcar estão sendo gradativamente sujeitas a um oligopólio liderado por esses grandes agentes econômicos (SANTOS, 2017).

A presença de agentes fortemente capitalizados resultou, por fim, na modernização técnico-produtiva e na expansão territorial do setor sucroenergético, incorporando novas áreas para a produção e processamento da cana-de-açúcar, sobretudo em regiões abrangidas pelo domínio morfoclimático do Cerrado (AB'SABER, 2003). De acordo com Castillo (2015), dois vetores preferenciais de expansão sucroenergética se formaram nos últimos anos a partir do Oeste Paulista: 1) Triângulo Mineiro / Cerrado Goiano e 2) norte do Paraná / Mato Grosso do Sul. Para Camelini; Castillo (2012), estas áreas "possuem a enorme vantagem da contiguidade em relação a São Paulo, sede dos principais grupos usineiros, das indústrias de bens de capital e serviços associados, dos centros de biotecnologia e destino da produção encaminhada à exportação". Nesse contexto, a mesorregião Triângulo Mineiro/Alto Paranaíba se tornou uma das áreas preferenciais para novos investimentos, culminando em grande expansão recente da atividade canavieira liderada, sobretudo, por grandes grupos atuantes no setor.

\section{A EXPANSÃO DO SETOR SUCROENERGÉTICO NO TRIÂNGULO MINEIRO/ALTO PARANAÍBA}

Embora a cana-de-açúcar tenha estado presente desde o início do século XIX no Triângulo Mineiro/Alto Paranaíba, foi só a partir da década de 1970 que ocorreu uma forte expansão de suas lavouras na mesorregião, com a institucionalização do Programa Nacional do Álcool (Proálcool). Pereira (2011), a partir de uma análise histórica, identifica três diferentes períodos que compõem o processo de desenvolvimento, organização e expansão da atividade canavieira na região.

O primeiro período (e também o mais longo) compreende o início do século XIX até meados do século $X X$, caracterizado pelas práticas rústicas de plantio e processamento da cana-de-açúcar e também da produção, em termos artesanais, de gêneros consumidos na região, como o açúcar (para rapadura e melaço) e a aguardente. Os engenhos eram tocados por escravos e as moendas, movidas por animais. Segundo Lourenço (2010) apud Pereira (2011), existiam ao menos 37 dessas unidades entre os anos de 1860-1870, distribuídas em uma área que atualmente compreende os municípios de Uberaba/MG, Campo Florido/MG, Conceição das Alagoas/MG, Frutal/MG e Uberlândia/MG. A primeira usina para a produção em moldes industriais de açúcar e melaço foi instalada em Sacramento/MG, em 1904, operando até hoje na área que atualmente compreende o município de Conquista/MG.

O segundo período corresponde à década de 1970 até o início da década de 2000, marcado pela expansão significativa da atividade canavieira impulsionada pelo Proálcool. A forte ampliação dos canaviais paulistas naquele momento acabou se estendendo para o Triângulo Mineiro, sobretudo nas áreas próximas à divisa com São Paulo, que convencionou-se chamar de "Pontal do

Estudos Geográficos, Rio Claro, 15(1): 106-132, jan./jun. 2017 (ISSN 1678-698X) http://www.periodicos.rc.biblioteca.unesp.br/index.php/estgeo 
Triângulo Mineiro". Alguns usineiros paulistas investiram na instalação de novas plantas na região, aproveitando o momento favorável do mercado para o setor. De acordo com Pereira (2011), esse é um novo período para a atividade sucroalcooleira na região, pois o setor passa a se organizar em decorrência de demandas do mercado nacional, principalmente do álcool combustível.

O meio geográfico da região transformou-se com a implantação de um trabalho moderno, racionalizado e realizado sob produção em larga escala, com maior mecanização das etapas produtivas, grandes extensões de terras e usinas de grandes proporções. Além disso, vários pequenos (e precários) núcleos urbanos ganharam novo dinamismo econômico, atrelado à especialização territorial produtiva. Até 1975, existiam três unidades de processamento de cana-de-açúcar na região, sendo que durante a vigência do Proálcool, ou seja, até 1990, mais cinco outras unidades foram instaladas, nos municípios de Pirajuba/MG, Iturama/MG, Canápolis/MG, Capinópolis/MG e Tupaciguara/MG. A instalação dessas usinas/destilarias respondeu por um aumento de 95,2 mil hectares de terras ocupadas por cana-de-açúcar entre os anos 1975 e 1990, ou seja, de 8.579 hectares para 103.862 hectares (IBGE, 1979; PAM/IBGE, 2016).

$\mathrm{Na}$ década de 1990, marcada pela desregulamentação estatal e pela reestruturação do setor sucroalcooleiro nacional, houve uma reorganização do capital canavieiro no Triângulo Mineiro, com a entrada, sobretudo, de grupos tradicionais provenientes do Nordeste. De acordo com Campos (2014), nessa época muitos usineiros nordestinos realizaram investimentos para a aquisição de terras, instalação de novas usinas/destilarias e/ou aquisição de outras unidades na região Centro-Sul. Tais ações visavam obter maiores ganhos nessas novas áreas de expansão do setor, em resposta aos problemas associados às dificuldades naturais e econômicas de produção que viam ocorrendo no Nordeste $^{5}$. Pereira (2011) resume esse movimento de reorganização do capital canavieiro que ocorreu até o ano 2001:

A usina de Canápolis é incorporada ao grupo alagoano João Lyra em 1988, e, mais tarde, é a vez da usina de Iturama ser adquirida, em 1994, pelo grupo alagoano Tércio Wanderley. Outro grupo alagoano, o Carlos Lyra (Usinas Caeté) implanta uma unidade industrial em Conceição das Alagoas no ano de 1996, e adquire em 2000 de usineiros paulistas uma usina no município de Delta (uma das maiores da região). Em 2001, o grupo João Lyra incorpora uma usina localizada em Capinópolis (PEREIRA, 2011, p. 4).

Entre 1990 e 2002, a região Triângulo Mineiro/Alto Paranaíba ganhou mais três unidades de processamento de cana-de-açúcar (municípios de Ibiá/MG, Fronteira/MG e Conceição das Alagoas/MG) e teve outras ampliadas e modernizadas, com a participação principalmente de grupos empresariais

\footnotetext{
${ }^{5}$ De acordo com Oliveira (2009), os principais fatores da crise do setor canavieiro no Nordeste eram a falta de terras para a expansão das lavouras, baixa fertilidade dos solos, deficiência hídrica e irregularidade das precipitações, topografia acidentada (que dificulta a implantação do recente modelo de mecanização da colheita) e a grande distância desta região em relação aos principais centros consumidores, que eleva os custos com logística e diminui a competitividade do açúcar e etanol frente aos produtores do Centro-Sul.

Estudos Geográficos, Rio Claro, 15(1): 106-132, jan./jun. 2017 (ISSN 1678-698X)

http://www.periodicos.rc.biblioteca.unesp.br/index.php/estgeo
} 
nordestinos ${ }^{6}$. Porém, assim como ocorreu em todo o Brasil, o crescimento do setor foi muito mais lento do que no período sob intensa regulação estatal e ancorado no Proálcool, dada a crise de consumo do álcool combustível. $\mathrm{O}$ crescimento da área plantada com cana-de-açúcar no Triângulo Mineiro aumentou apenas 14,7 mil hectares entre 1990 e 2002 (PAM/IBGE, 2016), ante os 95,2 mil no período anterior (1975-1990).

O terceiro e atual período é o que corresponde à retomada da expansão do setor sucroenergético em todo o país e, consequentemente, no Triângulo Mineiro/Alto Paranaíba. O mercado aquecido de etanol, açúcar e bioeletricidade contribuiu para a ampliação e modernização das unidades agroindustriais sucroenergéticas (UAS) existentes e a instalação de novas, o que exigiu a ocupação de mais terras para a cultivo da cana-de-açúcar. Conforme observou Pereira (2011), o momento recente é marcado pelo aporte de grandes investimentos de grupos nacionais e estrangeiros no setor, com operações de fusões e/ou aquisições de unidades agroindustriais e ampliação do cultivo canavieiro em vários municípios da mesorregião. Transnacionais como a Bunge (Holanda/EUA), Cargill (EUA), Archer Daniels Midland Company (ADM - EUA), Dow Chemical Company (EUA), British Petroleum (BP Biofuels Inglaterra), Mitsui \& CO. Ltda. (Japão), Indofood Agri Resources (Indonésia), são exemplos de agentes que realizaram investimentos recentes e promoveram a internacionalização do setor sucroenergético no Triângulo Mineiro/Alto Paranaíba.

Além disso, Pereira (2011) aponta as principais reconfigurações espaciais ocorridas no Triângulo Mineiro/Alto Paranaíba nesse novo período de expansão do setor sucroenergético, a partir das implicações territoriais decorrentes deste processo: substituição de culturas agrícolas e ocupação de áreas de pastagens (podemos incluir também muitas áreas de matas nativas do Cerrado); a oligopolização do setor, com aquisições e fusões de grupos nacionais e estrangeiros (principalmente a partir da crise econômica e financeira internacional de 2007-2008); subordinação dos proprietários de terras em relação às usinas/destilarias, mediante política agressiva de arrendamento de terras ou "terceirização" da produção da cana (contratos de fornecimento); ampla mobilização de políticas públicas (federais, estaduais e municipais) para viabilizar a expansão do parque das unidades agroindustriais (crédito do Banco Nacional de Desenvolvimento Econômico e Social - BNDES e Banco de Desenvolvimento de Minas Gerais - BDMG, incentivos fiscais, doações de terrenos, investimentos em logística, etc.); e forte especialização produtiva de alguns municípios, resultando em uma grande vulnerabilidade territorial associada, sobretudo, à extrema dependência econômica em relação à atividade canavieira.

Atualmente, o Triângulo Mineiro/Alto Paranaíba é, entre as mesorregiões, o maior cultivador e produtor de cana-de-açúcar no estado de Minas Gerais, seguida pelo Noroeste de Minas e pelo Sul/Sudoeste de Minas. Em 2015, com uma lavoura de 632,1 mil hectares e uma produção de 49,2 milhões de toneladas, concentrou $68,8 \%$ de toda a área plantada e $71,3 \%$ de toda a produção de cana-de-açúcar do estado. Na safra 2015/2016, também foi responsável por produzir $82 \%$ do açúcar e $73 \%$ do etanol (SIAMIG, 2016). O

\footnotetext{
${ }^{6}$ Segundo Campos (2014), os principais empresários nordestinos ligados ao agronegócio canavieiro que realizaram investimentos no Triângulo Mineiro/Alto Paranaíba foram: Tércio Wanderley, João Lyra, Carlos Lyra, João Pessoa e João Tenório.

Estudos Geográficos, Rio Claro, 15(1): 106-132, jan./jun. 2017 (ISSN 1678-698X)

http://www.periodicos.rc.biblioteca.unesp.br/index.php/estgeo
} 
estado de Minas Gerais, por sua vez, foi o segundo maior cultivador e o terceiro maior produtor de cana-de-açúcar no país na safra 2015/2016 (só perdendo para São Paulo e Goiás), com uma área de 1.071.934 de hectares de cana plantada e uma produção de 64,8 milhões de toneladas. O estado também se posicionou em segundo lugar na produção de açúcar (3,2 milhões de toneladas) e em terceiro lugar na produção de etanol (quase 3,1 bilhões de litros) na mesma safra (UNICADATA, 2017).

\section{O CRESCIMENTO DO NÚMERO DE UAS NA REGIÃO}

No período de 2000 a 2016 observa-se um grande crescimento do número de UAS instaladas na mesorregião Triângulo Mineiro/Alto Paranaíba, passando de 10 em 2000 para 25 UAS em 2015, sendo que no ano de 2011 houve o fechamento definitivo de uma unidade (a Destilaria Rio Grande, no município de Fronteira/MG) (gráfico 1). De acordo com a Procana (2015), mais cinco UAS estão em fase de projeto para os próximos anos, sendo uma da empresa Raízen (município de Prata/MG), uma da Concrenor (município de Araguari/MG) e três do grupo nacional Tércio Wanderley (municípios de Campo Florido/MG, Prata/MG e União de Minas/MG), que já possui quatro unidades na região. Porém, a Companhia Mineira de Açúcar e Álcool (CMAA, 2016) possui projeto de mais duas UAS: a Usina Uberlândia e a Usina Floresta do Lobo, ambas no município de Uberlândia/MG. Tal informação não consta no Procana (2015), mas nos indica que, com mais essas duas unidades, é possível que estejam previstos para os próximos anos a inauguração de mais sete novas UAS na região (mapa 1).

\section{Gráfico 1 - Triângulo Mineiro/Alto Paranaíba: evolução do número de UAS,} 2000-2016

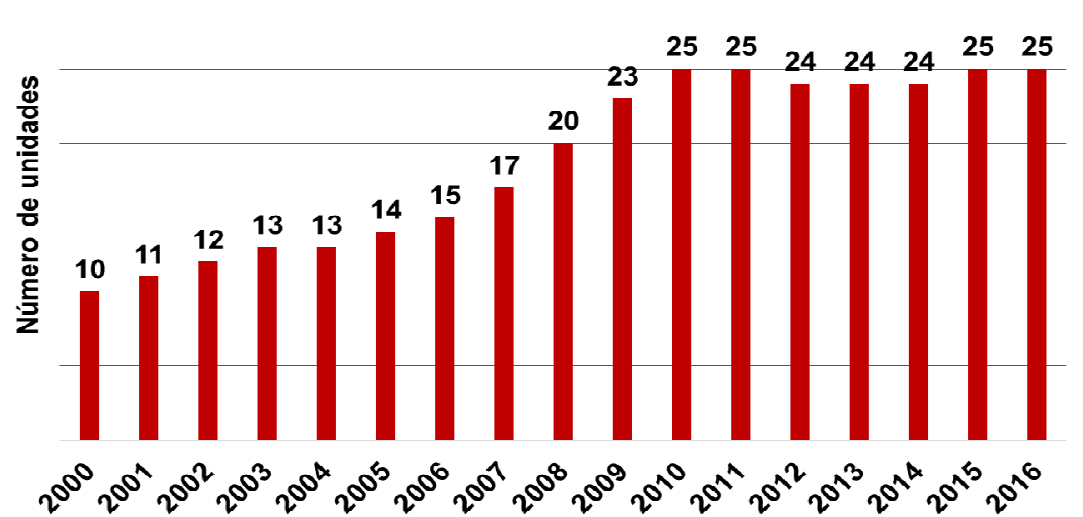

Fonte: Campos (2014), PROCANA (2015), INFOCANA (2017), NovaCana (2017), websites das empresas. Organização: autor

Atualmente, das 38 UAS existentes no estado de Minas Gerais, 25 estão localizadas na mesorregião Triângulo Mineiro/Alto Paranaíba, sendo cinco controladas majoritariamente por grupos de capital estrangeiro e 19 por grupos de capital nacional. Segundo a NovaCana (2017), até fevereiro de 2017, duas UAS se encontravam em processo de recuperação judicial na mesorregião, mantendo suas operações suspensas: a Companhia Energética Vale do São Simão (Grupo Andrade), no município de Santa Vitória/MG; e a Planalto Agroindustrial, no município de Ibiá/MG. Além dessas, mais duas unidades se Estudos Geográficos, Rio Claro, 15(1): 106-132, jan./jun. 2017 (ISSN 1678-698X) http://www.periodicos.rc.biblioteca.unesp.br/index.php/estgeo 
encontravam falidas, mas com negociações para retomar suas atividades via leilão: a Usina Triálcool, no município de Canápolis/MG, e a Usina Vale do Paranaíba, no município de Capinópolis/MG, ambas do grupo João Lyra, fechadas desde 2012.

Na safra 2015/2016, o Triângulo Mineiro/Alto Paranaíba possuía 773,5 mil hectares de cana-de-açúcar distribuídos em 53 dos 66 municípios da mesorregião, sendo que 19 desses contavam com plantas industriais de açúcar e/ou etanol, respondendo juntos por aproximadamente $70 \%$ da produção regional (UNICADATA, 2017). Como podemos ver no mapa 1, os municípios que possuem UAS são, em sua maior parte, os que mais produzem cana-deaçúcar, demonstrando, portanto, a forte influência que a agroindústria canavieira exerce sobre a produção agrícola local.

Mapa 1 - Triângulo Mineiro/Alto Paranaíba: produção municipal de cana-deaçúcar (toneladas) e localização das UAS, 2015

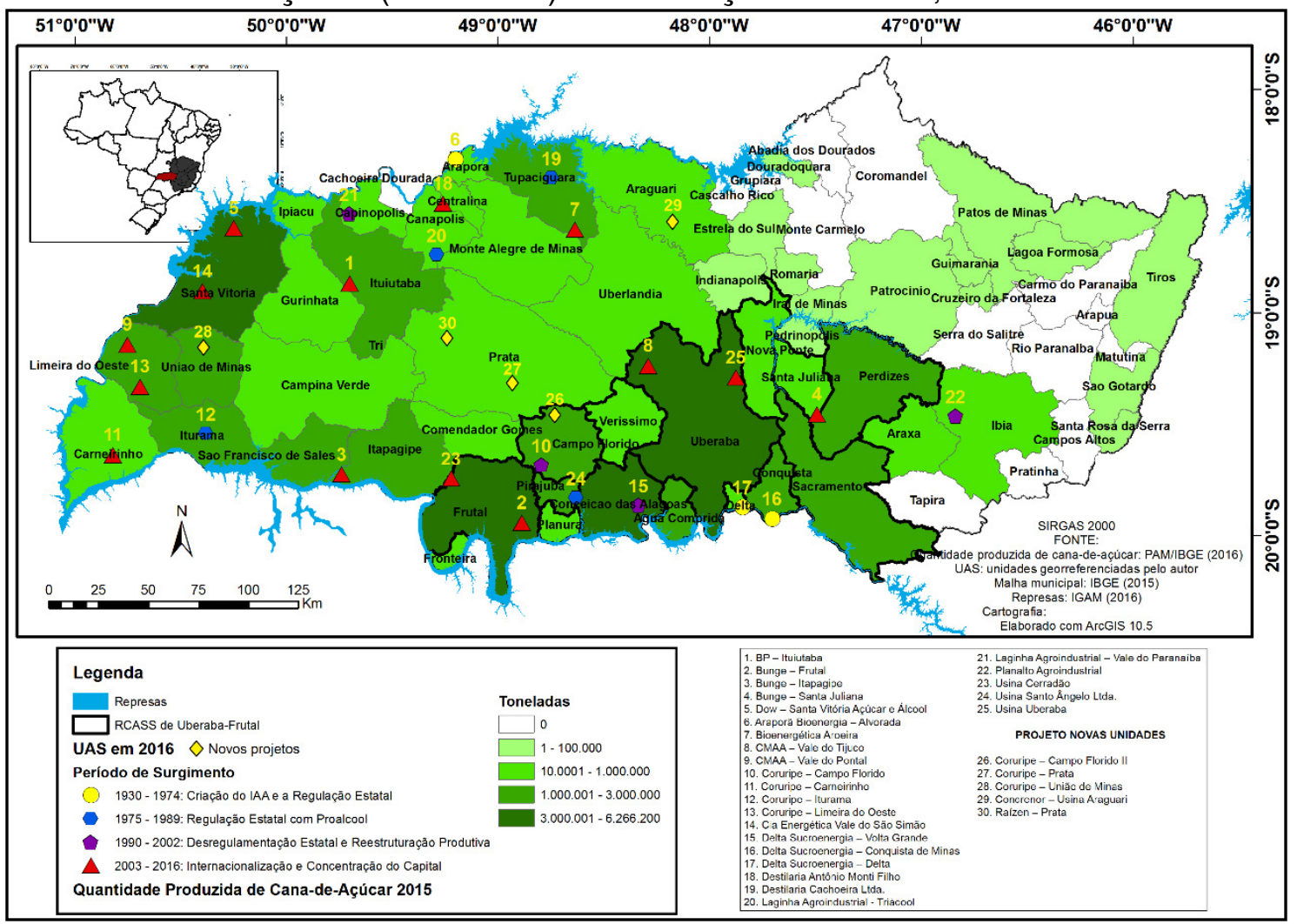

Fonte: Produção Agrícola Municipal - PAM (IBGE, 2016); PROCANA (2015).

Cartografia: autor

O crescimento do número de UAS na região deveu-se aos investimentos realizados sobretudo por grandes grupos atuantes no setor, tanto aqueles de capital nacional quanto os de capital transnacional.

\section{OS PRINCIPAIS GRUPOS ECONÔMICOS E A PRESENÇA DO CAPITAL ESTRANGEIRO NO SETOR SUCROENERGÉTICO}

Atualmente, o setor sucroenergético do Triângulo Mineiro/Alto Paranaíba é controlado por alguns grupos econômicos que atuam especificamente no ramo ou também em outras atividades agrícolas e/ou agroindustriais. Ao longo

Estudos Geográficos, Rio Claro, 15(1): 106-132, jan./jun. 2017 (ISSN 1678-698X) http://www.periodicos.rc.biblioteca.unesp.br/index.php/estgeo 
A dinâmica da recente expansão do setor sucroenergético...

das duas últimas décadas, ocorreram várias operações de aquisição de unidades brownfield e construção de novas unidades greenfield, envolvendo grandes grupos nacionais e estrangeiros. Os principais grupos de capital majoritariamente nacional que possuem UAS na região são: Tércio Wanderley, Delta Sucroenergia e Companhia Mineira de Açúcar e Álcool (CMAA). Já os grupos de capital estrangeiro são: Bunge, Dow Chemical e British Petroleum (BP Biofuels).

O grupo Tércio Wanderley é um tradicional investidor do setor sucroalcooleiro nordestino, originário do estado de Alagoas, onde possui a unidade matriz Coruripe, adquirida em 1941 e localizada no município homônimo. O grupo adquiriu, no estado de Minas Gerais, o primeiro empreendimento sucroalcooleiro (a antiga Destilaria Alexandre Balbo, que operava desde 1985) no município de Iturama/MG, em 1994. Posteriormente, o grupo construiu mais três unidades, nos municípios de Campo Florido/MG (2001), Limeira do Oeste/MG (2005) e Carneirinho/MG (2008). Hoje o Tércio Wanderley é o maior grupo do setor sucroenergético no Triângulo Mineiro/Alto Paranaíba, detentora de quatro unidades agroindustriais, além da usina alagoana, que integram as chamadas "Usinas Coruripe". Juntas, totalizam uma capacidade de moagem de 13,5 milhões de toneladas de cana-de-açúcar por safra e produção anual de 1 milhão de toneladas de açúcar, 449 milhões de litros de etanol e $697 \mathrm{MWh}$ de bioeletricidade. O grupo pretende ainda implantar mais três unidades sucroenergéticas na região, nos municípios de Campo Florido/MG (segunda unidade no local), União de Minas/MG e Prata/MG (USINA CORURIPE, 2016; PROCANA, 2015).

O Delta Sucroenergia, por sua vez, é um grupo recentemente criado a partir da cisão do grupo nordestino Carlos Lyra, ocorrida em 2012, em que parte do patrimônio foi transferida para o filho do patriarca alagoano, Robson Lyra, que passou a controlar as três usinas de Minas Gerais (antigas "Usinas Caeté"): a Unidade Delta, localizada no município de Delta/MG; a Unidade Conquista de Minas, no município de Conquista/MG; e a Unidade Volta Grande, no município de Conceição das Alagoas/MG. Atualmente, o grupo Delta Sucroenergia possui uma capacidade total de moagem de aproximadamente 10 milhões de toneladas de cana por safra e produção de 760 mil toneladas de açúcar, 310 milhões de litros de etanol e quase $400 \mathrm{MWh}$ de bioeletricidade (DELTA SUCROENERGIA, 2016; PROCANA, 2015).

Já a Companhia Mineira de Açúcar e Álcool (CMAA) foi criada em 2006 pela junção de capitais da empresa brasileira Vinci Partners com a do fundo de investimentos ZBI Ventures (Ziff Brothers Investments). Com a saída desses dois investidores do quadro societário da empresa, atualmente a CMAA é controlada pela brasileira JFCitrus Agropecuária, que adquiriu 50\% das ações da companhia, e a Indofood Agri Resources (IndoAgri), uma grande empresa de agronegócios e alimentos da Indonésia que passou a deter os outros $50 \%$ (NOVACANA, 2013a). Até o momento, a CMAA conta com duas UAS: a Vale do Tijuco, localizada no município de Uberaba/MG, e a Cabrera Energética, localizada no município de Limeira do Oeste/MG. A companhia adquiriu esta última unidade recentemente (2016) da multinacional estadunidense ADM, que saiu definitivamente do setor sucroenergético (DIÁRIO DO COMÉRCIO, 2016). Além dessas, a CMAA cogita mais dois projetos: a Usina Uberlândia e a Usina Floresta dos Lobos, ambos no município de Uberlândia/MG (CMAA, 2016). Se esses investimentos se confirmarem, a CMAA pode se tornar, nos próximos

Estudos Geográficos, Rio Claro, 15(1): 106-132, jan./jun. 2017 (ISSN 1678-698X) http://www.periodicos.rc.biblioteca.unesp.br/index.php/estgeo 
anos, o segundo maior grupo do setor sucroenergético da região, perdendo apenas para o grupo Tércio Wanderley.

Dentre as empresas estrangeiras que mantêm UAS no Triângulo Mineiro/Alto Paranaíba, a estadunidense Bunge $^{7}$ é a que possui maior representatividade, detentora de três UAS na região, nos municípios de Ituiutaba/MG, Itapagipe/MG e Frutal/MG. Em 2007 a Bunge entrou no setor sucroenergético com a compra da Usina Santa Juliana, pertencente aos sócios da empresa Triunfo, controlada pelo então governador alagoano Teotonio Vilela Filho. Em 2010, a transnacional expande seus negócios com a consolidação da compra de $100 \%$ do grupo Moema (de capital nacional e pertencente às famílias Biagi e Junqueira), que possuía, além das duas UAS situadas nos municípios de Itapagipe/MG e Frutal/MG, outras três unidades nos municípios paulistas de Postes Gesdal/SP, Ouroeste/SP e Orindiúva/SP (EXAME, 2009). Tendo entrado no mercado mundial de açúcar como trading em 2006, hoje a Bunge é uma das maiores produtoras e exportadoras de açúcar e etanol do país, possuindo, além das três unidades de processamento de cana situadas em Minas Gerais, mais cinco distribuídas nos estados de São Paulo, Mato Grosso do Sul e Tocantins ${ }^{8}$. Juntas, as oito UAS podem moer aproximadamente 21 milhões de toneladas de cana-de-açúcar/safra (BUNGE, 2016).

A estadunidense The Dow Chemical Company ${ }^{9}$ e a japonesa Mitsui \& CO Ltda. são outros investidores estrangeiros que decidiram aplicar os seus capitais no setor sucroenergético brasileiro. Resultado de uma joint-venture entre estas duas corporações, a Usina Santa Vitória Açúcar e Álcool, inaugurada em 2015 no município de Santa Vitória/MG, possui capacidade de processamento de 2,7 milhões de toneladas de cana-de-açúcar e produção de até 240 milhões de litros de etanol por safra, além de fabricação de polietileno a base de cana (DOW, 2016). Porém, no final de 2015 a Mitsui anunciou a venda de sua parte do negócio para a Dow, num valor de $R \$ 200$ milhões, saindo definitivamente do setor sucroenergético (JORNAL DO PONTAL, 2015).

Já a BP Biofuels ${ }^{10}$, braço de energia renovável da petrolífera britânica British Petroleum, possui uma unidade agroindustrial no município de Ituiutaba/MG, construída em 2008 pela Companhia Nacional de Açúcar e

\footnotetext{
${ }^{7}$ A Bunge, de origem holandesa (1818) é, hoje, uma das maiores corporações transnacionais no ramo do agronegócio e alimentos do mundo (presente em mais de 35 países), atuando no Brasil desde 1905 e dedicando-se principalmente ao processamento, transporte e comercialização de grãos, oleaginosas, trigo, algodão, açúcar, etanol, sorgo e girassol, além de diversos produtos alimentícios processados. Entre fábricas, usinas, moinhos, portos, centros de distribuição, silos e instalações portuárias, a Bunge Brasil possui mais de 100 instalações distribuídas em 19 estados e no Distrito Federal (BUNGE, 2016).

8 As outras cinco UAS da Bunge são: Unidade Guariroba (Pontes Gestal/SP), Unidade Ouroeste (Ouroeste/SP), Moema (Orindiúva/SP), Unidade Monteverde (Pontaporã/MS) e Unidade Pedro Afonso (Pedro Afonso/TO) (BUNGE, 2016).

${ }^{9}$ A The Dow Chemical Company, de origem estadunidense (fundada em 1897), é uma corporação que atua em diversos ramos da economia, como indústria química, agricultura, transportes, infraestrutura e energia, contabilizando mais de 5.000 gêneros produzidos em 197 unidades fabris em 36 diferentes países. Está presente no Brasil desde 1956 e hoje possui 23 empreendimentos, concentrando 12 deles no estado de São Paulo (DOW, 2016).

${ }^{10}$ A British Petroleum (BP), fundada em 1908, é uma transnacional de origem britânica, cujo maior foco de investimento está na exploração de petróleo e gás natural e produção de seus subprodutos. Opera em mais de 70 países. Está presente no Brasil desde 1957 e hoje possui atividades em 14 estados e no Distrito Federal e atua nos seguintes segmentos: exploração de petróleo e gás natural, lubrificantes, biocombustíveis, distribuição de combustíveis marítimos e de aviação (BP, 2016).

Estudos Geográficos, Rio Claro, 15(1): 106-132, jan./jun. 2017 (ISSN 1678-698X) http://www.periodicos.rc.biblioteca.unesp.br/index.php/estgeo
} 
Álcool (CNAA) ${ }^{11}$ e que foi adquirida pela transnacional em 2011, com capacidade de processamento de aproximadamente 2,5 milhões de toneladas de cana/safra (BP, 2016). Além desta, a BP Biofuels controla mais duas UAS no estado de Goiás (municípios de Edéia/GO e Itumbiara/GO). Juntas, as três unidades sucroenergéticas somam uma capacidade de processamento de 6,2 milhões de toneladas de cana-de-açúcar e produção de 316,4 mil toneladas de açúcar e 315,8 milhões de litros de etanol (PROCANA, 2015).

A presença dessas corporações transnacionais marca, portanto, o processo de internacionalização do setor sucroenergético no Triângulo Mineiro/Alto Paranaíba, que se acentuou sobretudo a partir de 2008, quando algumas empresas nacionais que se encontravam em dificuldades financeiras, como foi o caso do Grupo Moema, do CNAA e do Grupo Cabrera, foram adquiridas pelos grupos estrangeiros supracitados. As aquisições de usinas/destilarias por grupos nacionais e transnacionais reforçaram, também, o processo de concentração de capital no setor, conforme constatou Teodoro (2016), com unidades que passaram a ser controladas por um número menor de companhias altamente capitalizadas, como é o caso, na região em estudo, das nacionais Coruripe (Tércio Wanderley), Delta Sucroenergia e CMAA, e das estrangeiras Bunge e BP Biofuels.

\section{EXPANSÃO DA ÁREA CULTIVADA, DA PRODUÇÃO CANAVIEIRA E DAS EXPORTAÇÕES DE AÇÚCAR E ETANOL}

O crescimento do número de UAS e o controle dessas unidades por grandes corporações nacionais e transnacionais com elevada capacidade de realizar investimentos é o principal fator responsável pela expansão acelerada, nos últimos 16 anos, das áreas ocupadas por cana-de-açúcar no Triângulo Mineiro/Alto Paranaíba. Houve um aumento de 505,6 mil hectares de área plantada da cultura entre 2000 e 2015, sendo que esse número, segundo dados da UNICADATA (2017), sobe para quase 653 mil hectares se considerarmos até a safra 2016/2017 (gráfico 3). Segundo Pereira (2012), essa expansão canavieira ocorreu nas melhores áreas da região e com intenso uso de técnicas modernas de produção agrícola.

No que se refere à expansão territorial do cultivo, há claro esforço de ocupação, por parte dos novos grupos que investem na instalação de usinas, das áreas com melhor qualidade de solo e passíveis de mecanização (topografia plana). Isso tem ocorrido a partir da substituição de áreas antes ocupadas por cultivos temporários (inclusive com alguma competição em áreas antes cultivadas com milho/soja), mas principalmente pela substituição de áreas de pastagem. Intenso em técnica e envolvendo agentes qualificados para um trabalho diretamente ligado à ciência e tecnologia (emprego de defensivos, corretivos, máquinas modernas para a colheita, remuneração a

\footnotetext{
11 A CNAA foi formada em 2007 a partir de uma joint-venture entre o grupo Santelisa Vale (hoje incorporada pela Louis Dreyfus Commodities - LDC) e um pool de fundos de investimentos estrangeiros, entre eles o Riverstone, do Carlyle Group, além do Goldman Sachs, Global Foods e Discovery Capital. Até 2011, a CNAA possuía duas unidades agroindustriais sucroenergéticas, que posteriormente passaram a pertencer à BP: a Ituiutaba Bioenergia (Ituiutaba/MG) e a Central Itumbiara de Bioenergia (Itumbiara/MG).

Estudos Geográficos, Rio Claro, 15(1): 106-132, jan./jun. 2017 (ISSN 1678-698X)

http://www.periodicos.rc.biblioteca.unesp.br/index.php/estgeo
} 
A dinâmica da recente expansão do setor sucroenergético...

partir de cálculo do teor de glicose nas plantas, etc.), o cultivo da cana de açúcar, da forma como tem atualmente se expandido na região, reforça o caráter da agricultura moderna e intensa em capital (PEREIRA, 2012, p. 96).

Como podemos ver no gráfico 2, houve um crescimento bastante acentuado da lavoura de cana-de-açúcar entre 2003 e 2015, ao contrário do que aconteceu com a soja, cuja área teve significativa redução. A partir de 2008, a área plantada com milho também diminuiu, o que reforça a ideia de que a cana-de-açúcar tem avançado sobretudo sobre as ocupações de lavoura temporária, embora a área plantada com soja venha se recuperando nos últimos sete anos. Uma das suposições para este caso seria o intenso uso da leguminosa para rotação de cultura no sistema de reforma do canavial, aumentando assim a área cultivada ao lado da cana.

Contudo, a área de cana-de-açúcar praticamente se igualou à área de soja em 2014, revelando uma tendência da lavoura canavieira de tomar o posto como principal cultivo no Triângulo Mineiro/Alto Paranaíba nos próximos anos (mesmo que tenha havido redução da área de cana em 2015, segundo o IBGE, o que não se confirma nos dados do UNICADADATA, 2017). É possível perceber também no gráfico 2 que o Triângulo Mineiro vem passando por um processo de especialização regional voltada para a produção de algumas commodities, como é o caso do açúcar (cana-de-açúcar), soja, milho e café. Em contrapartida, observa-se uma estagnação no avanço de outros cultivos, provenientes, em sua maior parte, da agricultura familiar.

\section{Gráfico 2 - Triângulo Mineiro/Alto Paranaíba: evolução da área plantada das} principais lavouras, 2000-2015

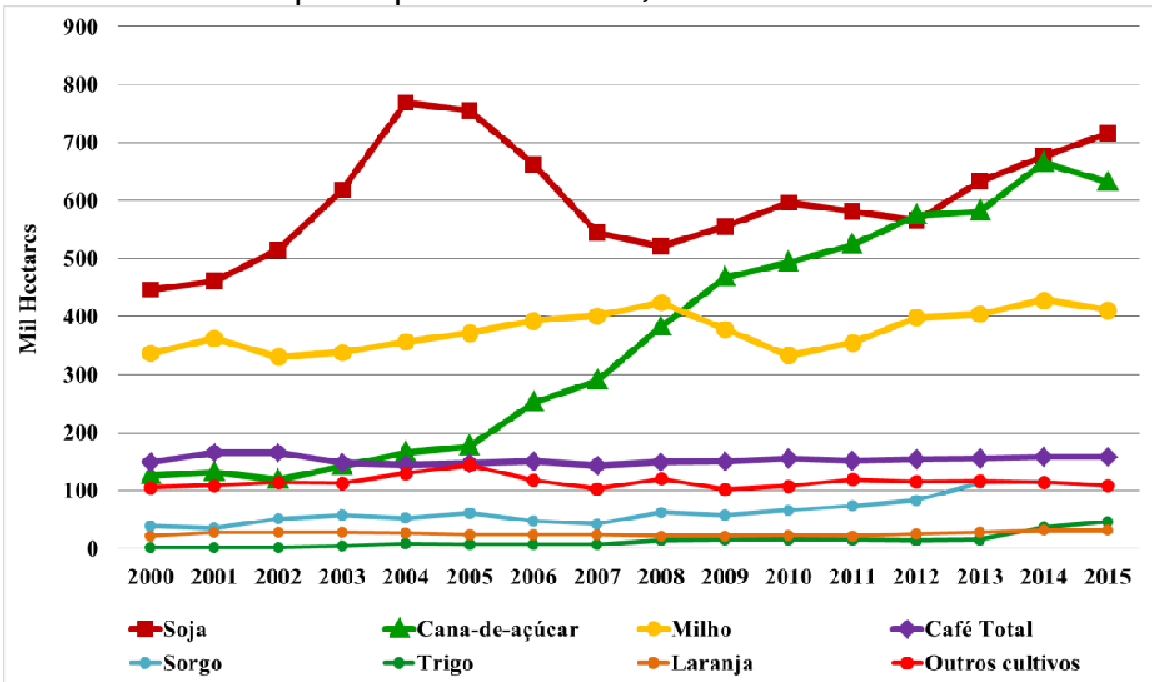

Fonte: Produção Agrícola Municipal - PAM (IBGE, 2016). Organização: autor

Assim, a área plantada com cana-de-açúcar elevou-se de 126,5 mil hectares em 2000 para 632,1 mil hectares em 2015, ou seja, um aumento de $400 \%$ (número que sobe para $515 \%$ se considerarmos até a safra de 2016/2017, de acordo com dados da UNICADATA, conforme mostra o gráfico 3). A produção de cana-de-açúcar também foi expressiva, passando de 10 milhões de toneladas para 49,2 milhões no mesmo período, representando um aumento de $389 \%$ (tabela 4). Observa-se também uma discreto aumento na

Estudos Geográficos, Rio Claro, 15(1): 106-132, jan./jun. 2017 (ISSN 1678-698X) http://www.periodicos.rc.biblioteca.unesp.br/index.php/estgeo 
produtividade da cana-de-açúcar na região. Conforme dados do PAM/IBGE, em 2001 o rendimento médio da cultura foi de 75,9 toneladas por hectare, aumentando gradualmente até 2009 , quando atingiu 87,9 toneladas/hectares, tendo depois sucessivas quedas, chegando a 78,7 toneladas/hectares em 2015 (tabela 4). Embora tivesse havido esta redução, o rendimento médio do último ano ficou acima do obtido no estado de Minas Gerais (76,2 ton./ha), em São Paulo (72,1 ton./ha) e no Brasil (70 ton./ha) (PAM/IBGE, 2016).

Tabela 4 - Triângulo Mineiro/Alto Paranaíba: área plantada, quantidade produzida e rendimento médio da cana-de-açúcar, 2000-2015

\begin{tabular}{cccc}
\hline Anos & $\begin{array}{c}\text { Área colhida } \\
\text { (hectares) }\end{array}$ & $\begin{array}{r}\text { Quantidade produzida } \\
\text { (toneladas) }\end{array}$ & $\begin{array}{c}\text { Rendimento médio } \\
\text { (ton./ha) }\end{array}$ \\
\hline 2000 & 126.500 & 10.076 .488 & 79,6 \\
2005 & 176.791 & 14.459 .650 & 81,7 \\
2010 & 492.440 & 42.415 .800 & 86,1 \\
2015 & 625.413 & 49.247 .252 & 78,7 \\
\hline
\end{tabular}

Fonte: Produção Agrícola Municipal - PAM (IBGE, 2016). Organização: autor

Gráfico 3 - Triângulo Mineiro/Alto Paranaíba: evolução da área cultivada de cana-de-açúcar, por situação da lavoura, safras 2005/2006-2016/2017

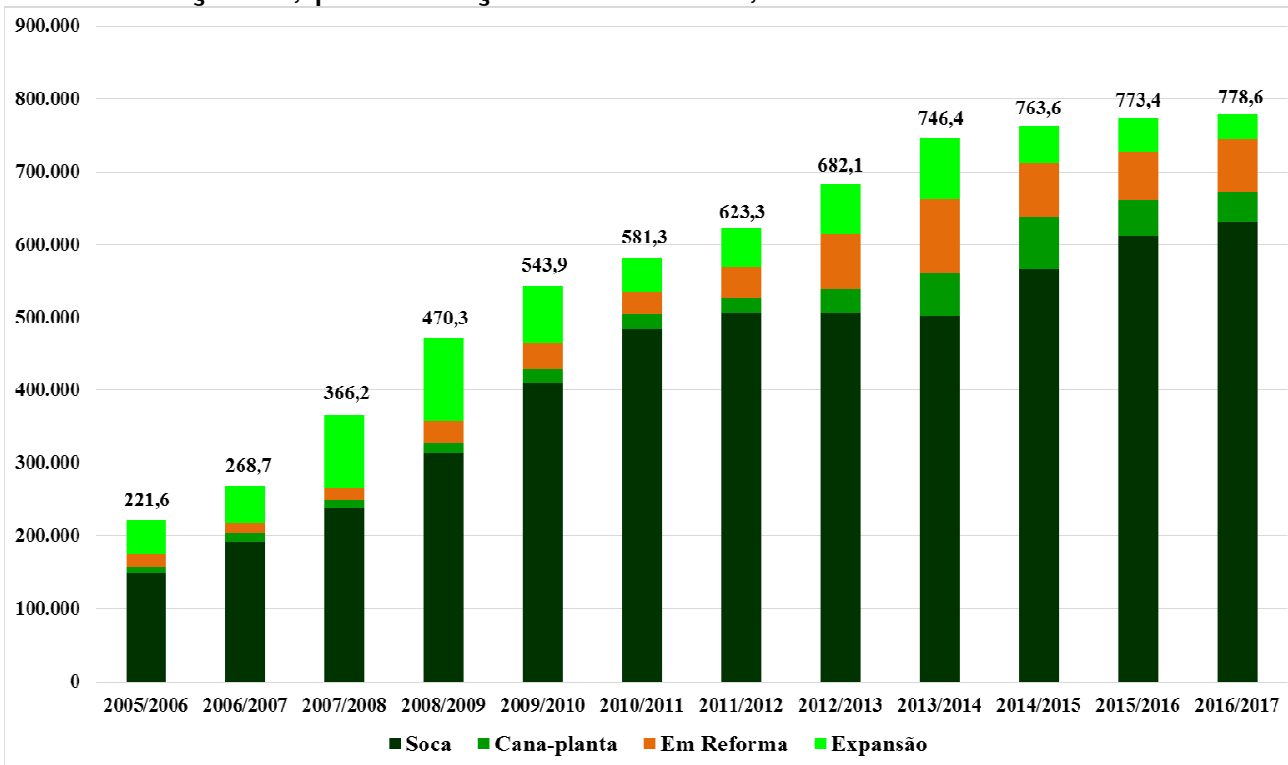

Fonte: UNICADATA (2017) a partir de dados do CANASAT/INPE

Desse modo, a região conheceu uma grande ampliação geográfica do agronegócio canavieiro, que transformou completamente a paisagem rural de vários municípios numa imensidão de canaviais. Em Uberaba/MG, maior produtor de cana-de-açúcar da mesorregião, por exemplo, a área plantada aumentou de 5 mil hectares em 2000 para 73,7 mil hectares em 2015. Em Frutal/MG, segundo maior produtor, a área plantada com cana-de-açúcar passou de 3,6 mil para 61,9 mil hectares. Em Santa Vitória/MG, terceiro maior produtor, a expansão foi de 40 hectares para 53,5 mil hectares. E em Campo Florido/MG, quinto maior produtor, a lavoura ampliou-se de 800 hectares para quase 32 mil hectares no mesmo período (tabela 5).

Estudos Geográficos, Rio Claro, 15(1): 106-132, jan./jun. 2017 (ISSN 1678-698X) http://www.periodicos.rc.biblioteca.unesp.br/index.php/estgeo 
Tabela 5 - Triângulo Mineiro/Alto Paranaíba: área plantada (hectares) de canade-açúcar nos dez maiores municípios canavieiros, 2000-2015 (anos selecionados)

\begin{tabular}{lccccccc}
\multicolumn{1}{c}{ Municípios } & 2000 & 2005 & 2010 & 2012 & 2013 & 2014 & 2015 \\
\hline Uberaba & 5.000 & 20.000 & 46.000 & 60.000 & 60.000 & 81.000 & 73.720 \\
Frutal & 3.600 & 8.228 & 30.689 & 49.000 & 57.000 & 62.140 & 61.972 \\
Santa Vitória & 40 & 5 & 25.867 & 28.400 & 31.400 & 45.000 & 53.500 \\
Conceição das Alagoas & 15.000 & 14.000 & 40.000 & 40.000 & 40.000 & 38.000 & 38.400 \\
Campo Florido & 800 & 12.600 & 17.500 & 20.000 & 20.000 & 29.930 & 31.844 \\
Iturama & 19.608 & 21.295 & 30.900 & 30.500 & 30.500 & 29.500 & 28.820 \\
Ituiutaba & 500 & 6.700 & 24.000 & 20.100 & 21.000 & 24.000 & 28.000 \\
Limeira do Oeste & 2.502 & 2.300 & 18.000 & 18.800 & 18.800 & 26.340 & 24.212 \\
Conquista & 11.000 & 7.500 & 15.000 & 15.000 & 15.000 & 19.000 & 18.200 \\
Água Comprida & 4.000 & 6.160 & 19.500 & 19.000 & 19.000 & 17.500 & 17.000 \\
\hline \multicolumn{4}{c}{ Fonte: Produção Agrícola Municipal - PAM (IBGE, 2016). Organização: autor }
\end{tabular}

Essa expansão canavieira ocorreu, segundo mapeamento feito por Reis (2013), entre 2000 e 2010, a partir de técnicas de interpretação de imagens de satélite (apenas na porção do Triângulo Mineiro), principalmente sobre áreas de pastagens ( $51 \%$ do total dos usos de solo convertidos) e atividades agrícolas (sobretudo soja e milho) (39\%), além da vegetação natural (10\%). Com base nos trabalhos de campo realizados na região, observamos que este perfil de conversão de usos do solo pela cana-de-açúcar continua ocorrendo, sobretudo, em áreas de pastagem e de agricultura, já que restam poucos fragmentos de vegetação natural na região face à intensa ocupação dos espaços rurais ocorrida nas décadas anteriores.

Os mapas 2 e 3, produzidos a partir de dados do projeto Canasat (2016) e da Agrosatélite Geotecnologia Aplicada ${ }^{12}$, mostram com precisão as áreas da região que mais sofreram expansão do setor sucroenergético entre 2005 e 2016. Podemos ver que a ampliação das lavouras e a instalação de novas UAS se deram sobretudo nas porções sul, onde já ocorria uma significativa produção canavieira desde a década de 1980, e a porção norte e leste, que se constituem nas novas fronteiras de expansão sucroenergética pós 2003. Notase que essas áreas são adjacentes aos grandes rios que delimitam a mesorregião, os Rios Grande e Paranaíba, o que significa o aproveitamento estratégico dos recursos hídricos (afluentes e rios principais) para as operações agrícolas e agroindustriais

\footnotetext{
${ }^{12}$ Dados (shapefile) obtidos mediante sitação.

Estudos Geográficos, Rio Claro, 15(1): 106-132, jan./jun. 2017 (ISSN 1678-698X)

http://www.periodicos.rc.biblioteca.unesp.br/index.php/estgeo
} 
A dinâmica da recente expansão do setor sucroenergético...

Mapa 2 - Triângulo Mineiro/Alto Paranaíba: espacialização da área cultivada com cana-de-açúcar e localização das UAS, 2005

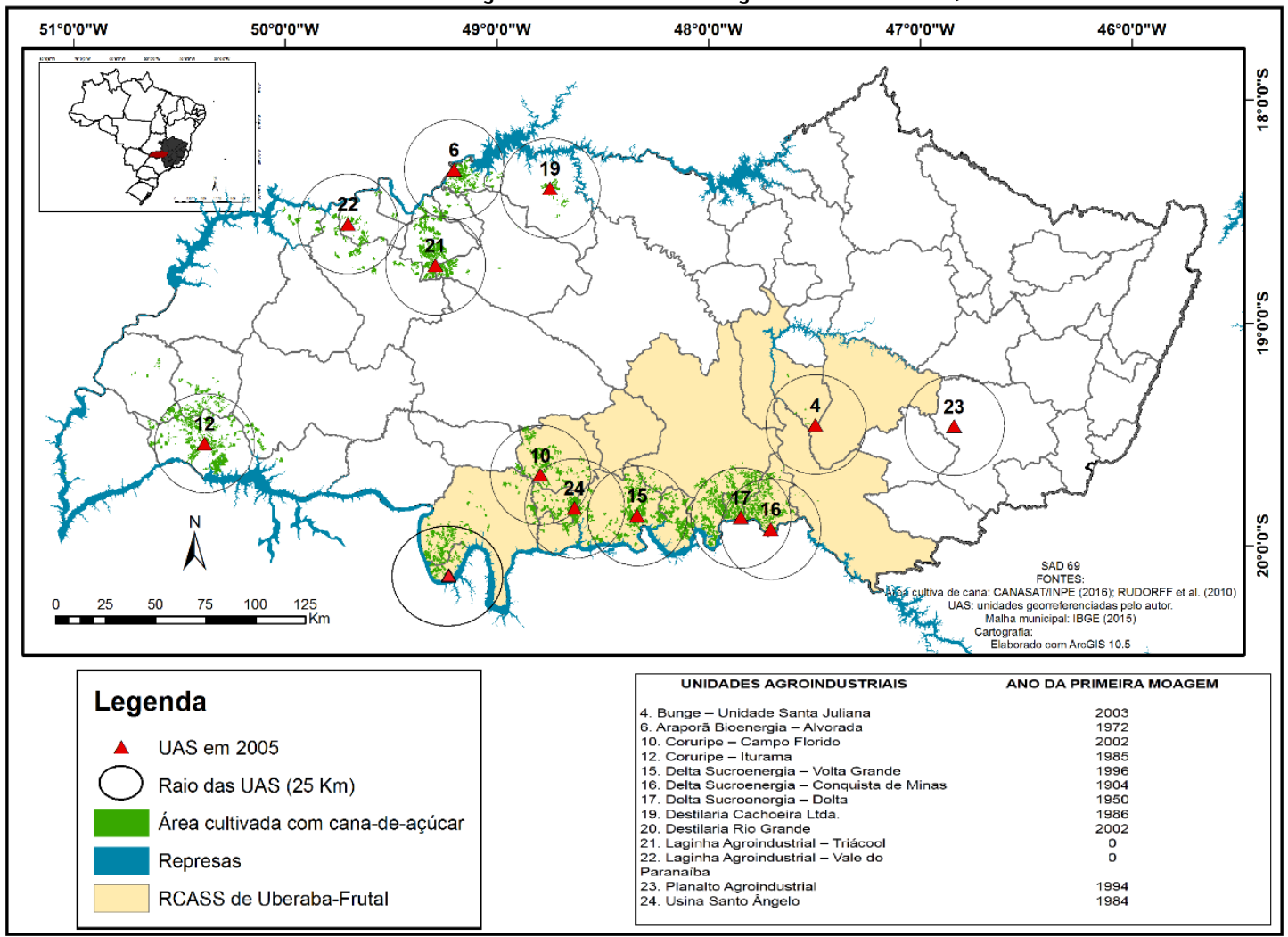

Fonte: CANASAT/INPE (2016); Rudorff et al. (2010). Cartografia: autor

Mapa 3 - Triângulo Mineiro/Alto Paranaíba: espacialização da área cultivada com cana-de-açúcar e localização das UAS, 2016

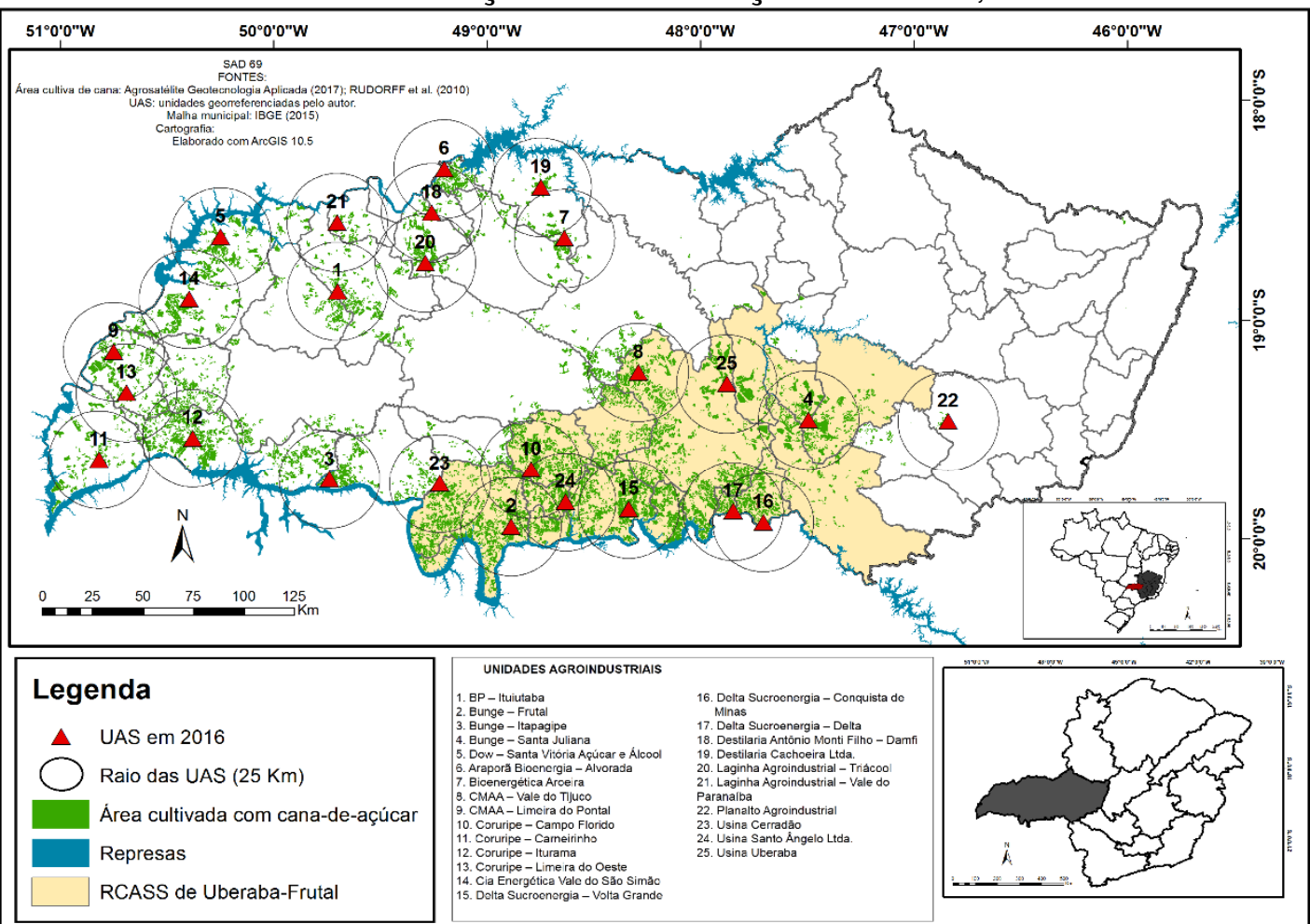

Fonte: Agrosatélite Geotecnologia Aplicada (2017); Rudorff et al. (2010).

Cartografia: autor

Estudos Geográficos, Rio Claro, 15(1): 106-132, jan./jun. 2017 (ISSN 1678—698X)

http://www.periodicos.rc.biblioteca.unesp.br/index.php/estgeo 
A espacialização do cultivo da cana-de-açúcar e a localização das UAS com o seu raio de alcance potencial $(25 \mathrm{Km})^{13}$ para abastecimento de matériaprima nos permite, finalmente, identificar as áreas efetivamente produtivas do agronegócio canavieiro e estudar as várias implicações de suas atividades nos principais municípios produtores. O aumento da área cultivada e do número de UAS resultou na elevação da capacidade produtiva e das exportações de açúcar e etanol da região.

O gráfico 4 mostra que houve um grande aumento do volume exportado de açúcar no estado de Minas Gerais entre 2000 e 2016, na ordem de 280 mil para 3,2 milhões de toneladas. Já o etanol obteve um tímido crescimento nas vendas entre 2005 e 2010, mas o volume exportado veio decrescendo nos últimos anos por conta de uma série de fatores que desestimularam o consumo internacional e a sua produção frente às demandas crescentes por açúcar. Considerando que a mesorregião participa, hoje, em mais de $70 \%$ da produção estadual de açúcar e etanol, estima-se que a sua participação nas exportações seja algo semelhante.

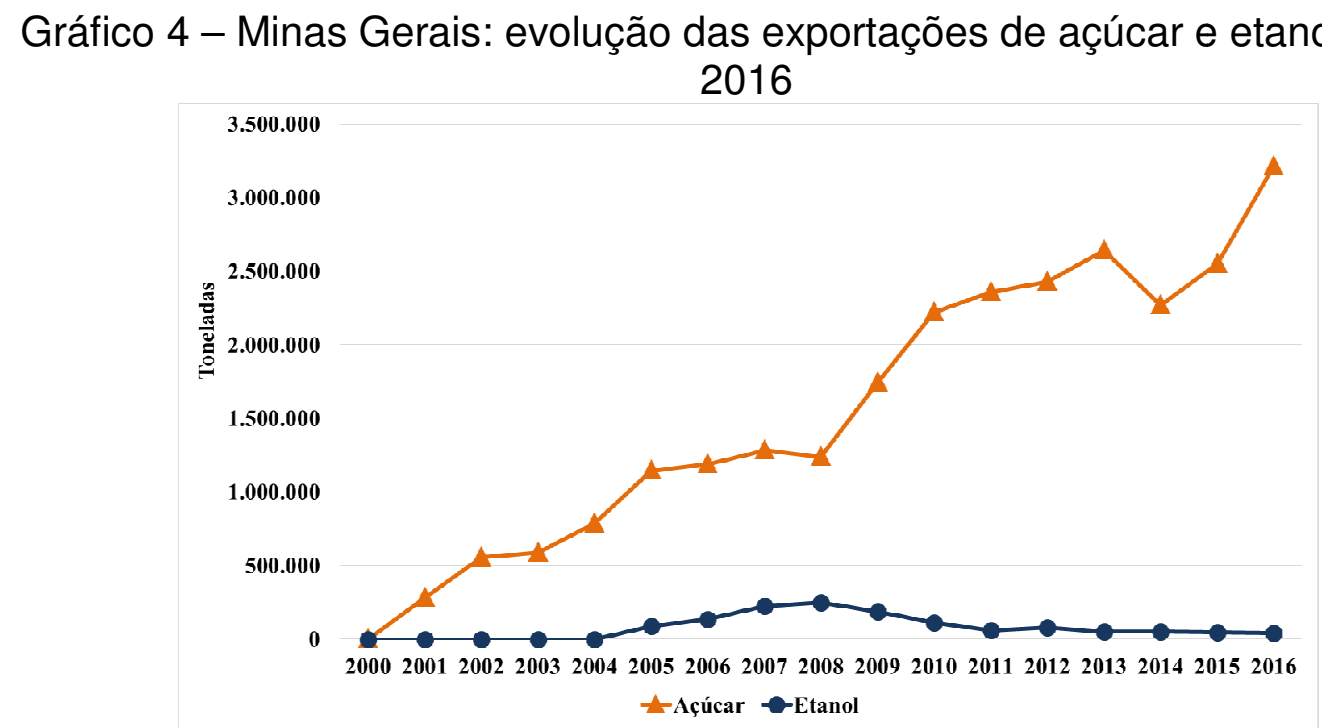

Fonte: Estatísticas de Comércio Exterior (MDIC, 2017). Organização: autor

A presença de uma densa malha rodoferroviária e de alguns nós logísticos $^{14}$ (BRAGA; CASTILLO, 2013) na região contribui para as exportações nos principais municípios produtores de açúcar e etanol. O mapa 4 expõe, por exemplo, que os municípios do Triângulo Mineiro/Alto Paranaíba com UAS instaladas, que possuem proximidade à terminais multimodais e à densa infraestrutura rodoferroviária, tiveram grandes saldos de exportação do setor

\footnotetext{
${ }^{13}$ Distância média percorrida do canavial até a agroindústria, para o estado de Minas Gerais (CONAB, 2017).

${ }_{14}$ De acordo com Braga; Castillo (2013, p. 239-240), os nós logísticos podem ser considerados como "híbridos de objetos técnicos e normas constituintes de uma rede de circulação e distribuição planejada, implantada e constantemente modificada no território e, assim como a própria logística, constituem-se em expressões do período técnico-científico e informacional. Esses nós possibilitam a conexão entre um ou vários modais de transporte (rodoviário, ferroviário, aeroviário, hidroviário e dutoviário), tendo como uma de suas principais funções a transferência intra e intermodal de mercadorias. Permitem o controle e o redirecionamento dos fluxos materiais e sua localização, concepção e uso tornam-se estratégicos para alguns agentes, lugares e circuitos espaciais produtivos." Os autores colocam como exemplos de nós logísticos os recintos aduaneiros, os terminais dutoviários, as centrais de distribuição, os grandes terminais aeroviários, aquaviários e ferroviários de cargas e as plataformas logísticas.
}

Estudos Geográficos, Rio Claro, 15(1): 106-132, jan./jun. 2017 (ISSN 1678-698X) http://www.periodicos.rc.biblioteca.unesp.br/index.php/estgeo 
sucroenergético em 2016, com destaque para Uberaba/MG, Frutal/MG, Delta/MG, Santa Juliana/MG, Campo Florido/MG, Pirajuba/MG e Uberlândia/MG. Uberlândia/MG, que não produz açúcar, exporta a commodity pelo Porto Seco do Cerrado, conectado a uma linha ferroviária operada pela VLI. No mais, o escoamento do açúcar de outros municípios à exportação ainda é feito predominantemente via modal rodoviário até alguns terminais de carga existentes no noroeste do estado São Paulo, como Guará/SP, Ribeirão Preto/SP, São José do Rio Preto/SP, Pradópolis/SP, Barretos/SP e Fernandópolis/SP. Estes terminais são controlados por grandes operadores logísticos, como a Rumo, a VLI e a Copersucar, e são ligados ao Porto de Santos via ferrovias, que também são controladas pela Rumo. Essas condições são responsáveis por uma maior eficiência logística regional do setor sucroenergético, conectando mais facilmente os municípios ao mercado internacional.

Mapa 4 - Triângulo Mineiro/Alto Paranaíba: exportações municipais do setor sucroenergético, malha rodoferroviária e localização dos nós logísticos e UAS,

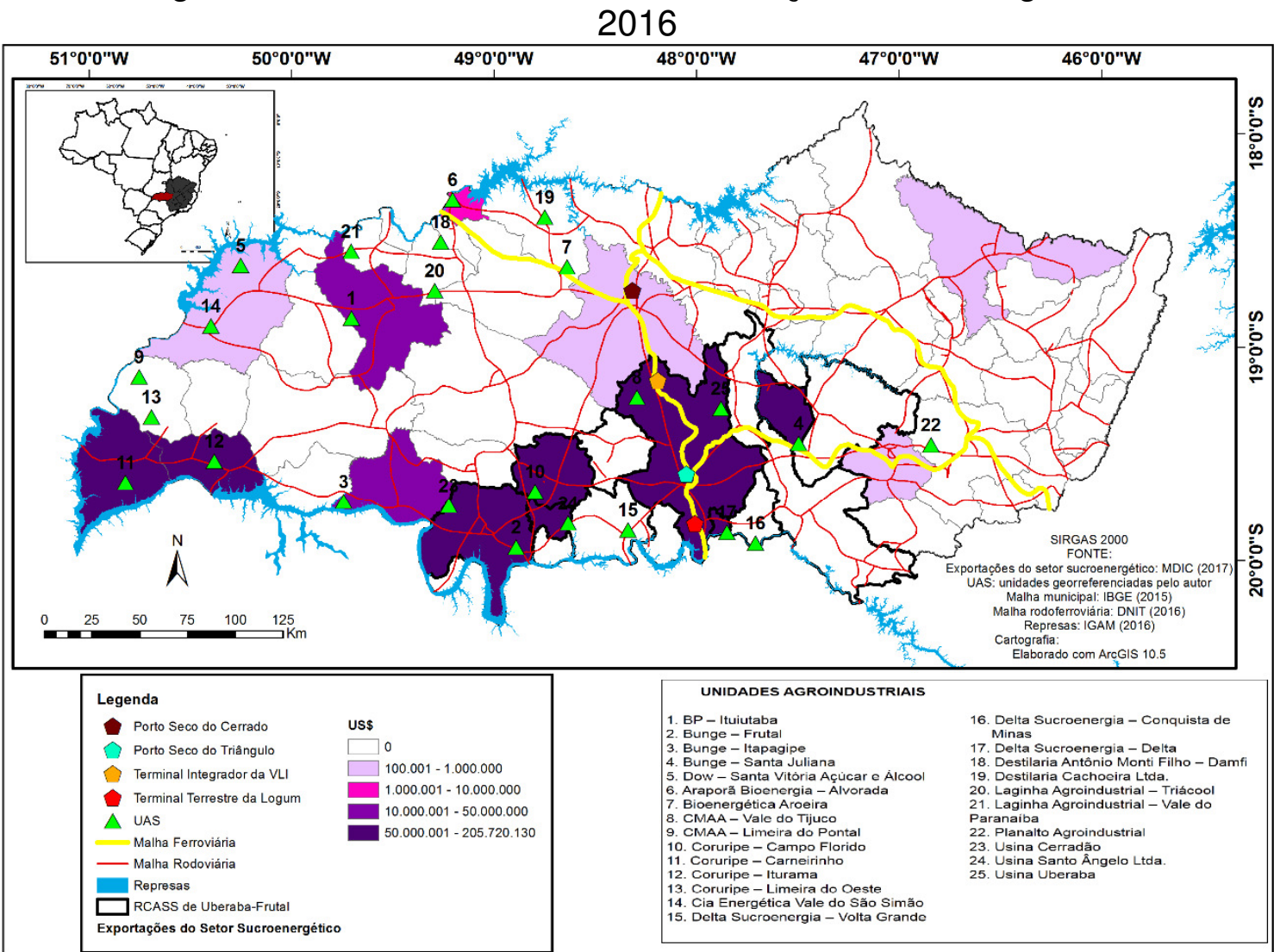

Fonte: Estatísticas de Comércio Exterior (MDIC, 2017). Cartografia: autor

Portanto, a maior presença de empresas estrangeiras controlando as UAS a o aumento das exportações de açúcar e etanol evidenciam um gradativo processo de internacionalização do setor sucroenergético no Triângulo Mineiro/Alto Paranaíba, favorecendo ganhos de competitividade nesta atividade do agronegócio nacional. 


\section{CONSIDERAÇÕES FINAIS}

Como a sistematização de dados e informações puderam mostrar, houve uma grande expansão do setor sucroenergético no Triângulo Mineiro/Alto Paranaíba entre os anos 2000 e 2016, muito atrelado às condições geográficas favoráveis de cultivo e processamento de cana-de-açúcar existentes na região (SANTOS, 2017) e aos investimentos realizados por grandes grupos nacionais e estrangeiros altamente capitalizados, alguns que recentemente se consolidaram no país. As possibilidades de comercialização do etanol combustível (anidro e hidratado) e da bioeletricidade no mercado interno e a elevação dos preços do açúcar no mercado internacional, explicam também os diversos investimentos na construção de unidades greenfields e na aquisição de unidades brownfields na região, elevando assim a capacidade de acumulação de capital dos agentes econômicos envolvidos no setor canavieiro.

Todavia, com os desdobramentos traumáticos da última crise econômica e financeira internacional de 2007-2008 no setor (MENDONÇA; PITTA; XAVIER, 2012), o processo de expansão sucroenergética acabou se estabilizando na região, sobretudo após o ano de 2013. Antes disso, haviam vários projetos de implantação de novas UAS, inclusive por empresas transnacionais. Embora ainda algumas unidades estejam previstas para serem implantadas, segundo consta no Anuário da Cana (PROCANA, 2015) percebemos, durante visitas a algumas UAS, que muitas obras ainda não saíram do papel ou foram paralisadas, em decorrência da recente diminuição dos recursos ofertados pelo BNDES, principal canal de financiamento das instalações agroindustriais.

Além da internacionalização ocorrida no setor sucroenergético e no incremento das exportações e receitas fiscais de alguns municípios de reduzido patamar demográfico (portanto, de baixo dinamismo econômico), as repercussões do crescimento da atividade canavieira vai muito além dos benefícios. Como já discutido, por exemplo, por Cleps Júnior (2009) e Pereira (2014), o rápido avanço da monocultura canavieira tem ocasionado diversas implicações socioambientais e econômicas nos principais municípios canavieiros da região. Devido principalmente a algumas características intrínsecas do setor sucroenergético (CASTILLO, 2015), como a restrição da armazenagem da matéria-prima e a semiperenidade da cultura, o cultivo da cana deve ocorrer, necessariamente, de forma intensiva e extensa, próxima às UAS, o que incorre em forte "engessamento" do uso da terra e do território (CASTILLO, 2015).

Sendo assim, as especializações regional e territorial produtivas (SILVEIRA, 2011) ligadas à atividade canavieira são inevitáveis levando, muitas vezes, à diminuição da diversidade produtiva no campo, ao aumento do desemprego, à concentração fundiária, à expropriação de trabalhadores e pequenos produtores rurais, à dependência econômica dos municípios às atividades do setor, à degradação de solos e recursos hídricos pelo monocultivo, ao desmatamento ilegal, entre outros problemas (SZMRECSANYI; GONÇALVES, 2009; THOMAZ JUNIOR, 2009). Esta situação foi denominada por Castillo; Camelini (2012) de "vulnerabilidade territorial" associada à expansão sucroenergética, e suas consequências merecem especial atenção por parte dos poderes públicos municipais e

Estudos Geográficos, Rio Claro, 15(1): 106-132, jan./jun. 2017 (ISSN 1678-698X) http://www.periodicos.rc.biblioteca.unesp.br/index.php/estgeo 
estadual, já que envolve problemas associados a supostas irregularidades cometidas pelos agentes do setor e extrema fragilização econômica de lugares altamente especializados e dependentes da atividade, em situações de repentinas paralisações temporária ou permanente de uma UAS.

\section{REFERÊNCIAS}

AB'SABER, Aziz. Os domínios de natureza no Brasil: potencialidades paisagísticas. São Paulo: Ateliê editorial, 2003.

ANP. Agência Nacional do Petróleo, Gás Natural e Biocombustíveis. Anuário estatístico brasileiro do petróleo, gás natural e biocombustíveis: 20012016. Disponível em: <http://www.anp.gov.br>. Acesso em: outubro/2016.

ANFAVEA. Associação Nacional dos Fabricantes de Veículos Automotores. Anuário da Indústria Automobilística Brasileira: 2016. Disponível em: <http://www.anfavea.com.br>. Acesso em: junho/2016.

BARBOSA, A. P. F. P. L. Mudança nos grupos estratégicos da indústria sucroalcooleira brasileira. Dissertação (Mestrado em Ciências). 78f. São Paulo: FEAC/USP, 2013.

BONSUCRO. Better Sugarcane Initiative. Portal Bonsucro. 2016. Disponível em:<http://www.bonsucro.com>. Acesso em: novembro/2016.

BRAGA, V.; CASTILLO, R. Tipologia e topologia de nós logísticos no território brasileiro: uma análise dos terminais ferroviários e das plataformas multimodais. Boletim Campineiro de Geografia, v. 3, nํ2, p. 235-258, 2013.

CAMELINI, J. H.; CASTILLO, R.A. Etanol e Uso Corporativo do Território. Mercator - Revista de Geografia da UFC, Fortaleza, v. 11, n. 25, p. 7-18, mai./ago. 2012.

CAMPOS, N. L. Redes do Agronegócio Canavieiro: a territorialização do Grupo Tércio Wanderley no Triângulo Mineiro/Alto Paranaíba - MG.

Dissertação (Mestrado em Geografia). 209f. Uberlândia: IG/UFU, 2014.

CANASAT/INPE. Instituto Nacional de Pesquisas Espaciais. Mapa de Cultivo. 2016. Disponível em: <http://www.dsr.inpe.br/laf/canasat>. Acesso em: dezembro/2016.

CASTILLO, R. Dinâmicas recentes do setor sucroenergético no Brasil: competitividade regional e expansão para o bioma Cerrado. Revista GEOgraphia, n. 35, p. 95-119, 2015.

CASTILLO, R. A expansão do setor sucroenergético no Brasil. In: BERNARDES, J. A.; SILVA, C. A.; ARRUZZO, R. C. (Org.). Espaço e energia: mudanças no paradigma sucroenergético. Rio de Janeiro: Lamparina, 2013, p. $75-84$.

Estudos Geográficos, Rio Claro, 15(1): 106-132, jan./jun. 2017 (ISSN 1678-698X) http://www.periodicos.rc.biblioteca.unesp.br/index.php/estgeo 
CGEE. Centro de Gestão e Estudos Estratégicos. Bioetanol de cana-deaçúcar: uma oportunidade para o Brasil. Brasília, DF: CGEE, 2009. Disponível em: <http://www.cgee.org.br/atividades/redirect.php?idProduto=5913>. Acesso em: junho/2015.

EPE. Empresa de Pesquisa Energética. Análise de conjuntura dos biocombustíveis: ano 2015. Disponível em: <www.epe.gov.br>. Acesso em junho/2016.

CLEPS JUNIOR, J. Concentração de poder no agronegócio e (des)territorialização: os impactos da expansão recente do capital sucroalcooleiro no Triângulo Mineiro. Caminhos de Geografia, v. 10, n. 31, p. 249-264, 2009.

CONAB. Companhia Nacional de Abastecimento. Perfil do setor do açúcar e do álcool no Brasil. V. 1 - Safra 2012/2013. Brasília: Conab, 2017. Disponível em:<http://www.conab.gov.br/conteudos.php?a=1701\&t=>. Acesso em: fevereiro/2017.

\section{DIÁRIO DO COMÉRCIO. CMAA adquire unidade da americana ADM.}

Reportagem, 04/05/2016. Disponível em:<https://goo.gl/4q4Hic>. Acesso em: Junho/2016.

EXAME. Bunge adquire 5 usinas do Grupo Moema por US\$ 1,5 bi. 2009. Disponível em: <http://exame.abril.com.br/negocios/noticias/bunge-adquire-5usinas-grupo-moema-us-1-5-bi-522279>. Acesso em: 30 de junho de 2016.

FAÇANHA, S. L. de O. Aquisições, fusões e alianças estratégicas na cadeia sucroenergética brasileira. Tese (Doutorado em Ciências) 339f. São Paulo: USP, 2012.

HARVEY, D. (2005). O Neoliberalismo: história e implicações. Trad. Adail Ubirajara Sobral, Maria Stela Gonçalves. 2 ed. São Paulo: Edições Loyola, 2011.

HIRST, P.; THOMPSON, G. Globalização em questão: a economia internacional e as possibilidades de governabilidade. Petrópolis: Vozes, 1998.

IBGE. Produção Agrícola Municipal (PAM), 2016. Disponível em: <http://www.sidra.ibge.gov.br>. Acesso em: junho/2016.

IBGE. Censo Agropecuário: Minas Gerais, 1975. Rio de Janeiro: IBGE, 1979.

INFOCANA. Portal da Infocana. 2017. Disponível

em:<https://www.infocana.com.br>. Acesso em: fevereiro/2017.

JORNALCANA. Companhia mineira surpreende e adquire nova usina.

Ribeirão Preto: JornalCana, n. 270, novembro de 2016, p. 7. Disponível em: <https://goo.gl/Olbujt>. Acesso em: dezembro/2016.

Estudos Geográficos, Rio Claro, 15(1): 106-132, jan./jun. 2017 (ISSN 1678-698X) 
JORNALCANA. Cresce fatia estrangeira na moagem de cana. Reportagem, 27/05/2015. Disponível em: <www.jornalcana.com.br>. Acesso em: Julho/2016.

JORNAL DO PONTAL. Empresa japonesa anuncia a venda de sua cota na usina Santa Vitória Açúcar e Álcool. 2015. Disponível em: $<\mathrm{https}: / / g o o . g l / d y m X d B>$. Acesso em: Dezembro/2016.

KPMG, Corporate Finance Ltda. Pesquisa de Fusão e Aquisição 2016 - 1ำ semestre. São Paulo: KPMG, 2016. Disponível em:

$<\mathrm{https}: / / \mathrm{home}$.kpmg.com/br/pt>. Acesso em: outubro/2016.

LEMOS, P. et al. Panorama e Desempenho Recente do Setor Sucroenergético: condições para um novo ciclo. Futuros do bioetanol: o Brasil na liderança? Rio de Janeiro: Elsevier, 2015, p. 9-33.

LOURENÇO, L. A. B. O Triângulo Mineiro, do Império à república: o extremo oeste de Minas Gerais na transição para a ordem capitalista (segunda metade do século XIX). Uberlândia: EDUFU, 2010.

MACÊDO, F. dos S. A reestruturação do setor sucroenergético no Brasil: uma análise do período entre 2005 e 2011. Dissertação (Mestrado em Agroenergia). 2011. 71f. São Paulo: EESP/FGV, 2011.

MAKIYA, I. K. Certificação do Setor Sucroenergético. In: SALLES-FILHO, Sérgio (Org.). Futuros do bioetanol: o Brasil na liderança? Rio de Janeiro: Elsevier, 2015, p. 91-110.

MAPA. Ministério da Agricultura, Pecuária e Abastecimento. Anuário Estatístico da Agroenergia 2014. Secretaria de Produção e Agroenergia. Brasília: MAPA/ACS, 2015.

MENDONÇA, M. L.; PITTA, F. T.; XAVIER, C. V. A Agroindústria Canavieira e a Crise Econômica Mundial. São Paulo: Outras Expressões, 2012. Disponível em: <www.social.org.br>. Acesso em: Julho/2016.

MDIC. Ministério do Desenvolvimento, Indústria e Comércio Exterior. Estatísticas de Comércio Exterior. Disponível em: <https://goo.gl/kdJi7D>. Acesso em: junho/2016.

NOVACANA. Portal NovaCana. 2017. Disponível em:<https://www.novacana.com>. Acesso em: fevereiro/2017.

NOVACANA. CMAA conclui processo de troca de acionistas. Reportagem, 27/06/2013a. Disponível em:<https://goo.gl/AFnzEe>. Acesso em: junho/2016.

NOVACANA. Estrangeiros são a nova geração de usineiros. Reportagem, 29/04/2013b. Disponível em: <https://goo.gl/0OTcOM>. Acesso em: setembro/2016. 
OLIVEIRA, A. M. Reordenamento territorial e produtivo do agronegócio canavieiro no brasil e os desdobramentos para o trabalho. Tese (Doutorado em Geografia). 611f. Presidente Prudente: FCT/UNESP, 2009.

PEREIRA, M. F. V. O Setor Sucroenergético no Triângulo Mineiro e as "Cidades da Cana". In: XXII ENCONTRO NACIONAL DE GEOGRAFIA AGRÁRIA. (Anais). Natal: UFRN, 2014, p. 2801-2816.

PEREIRA, M. F. V. Os agentes do agronegócio e o uso do território no Triângulo Mineiro/Alto Paranaíba: da moderna agricultura de grãos à expansão recente da cana-de-açúcar. Revista do Departamento de Geografia - USP, vol. 23, p. 83-104, 2012a.

PEREIRA, M. F. V. A cana-de-açúcar e as usinas sucroalcooleiras no Triângulo Mineiro: periodização e processo recente de expansão. In: IX ENANPEGE. (Anais). Goiânia: PPGEO/UFG, 2011, v. 1, p. 1-8.

PINTO, M. J. A. Investimentos diretos estrangeiros no setor sucroenergético. Dissertação (Mestrado em Administração de Organizações). 171f. Ribeirão Preto: FEAC/USP, 2011.

PITTA, F. T. As transformações na reprodução fictícia do capital na agroindústria canavieira paulista: do Proálcool à crise de 2008. Tese (Doutorado em Geografia). 420f. São Paulo: FFLECH/USP, 2016.

PROCANA. Anuário da Cana: Brazilian Sugar and Etanol Guide. 2015. Ribeirão Preto, 2015.

REIS, L. N. G. Mapeamento multitemporal e conversão do uso da terra a partir da expansão canavieira no Triângulo Mineiro (2000-2010).

Dissertação (Mestrado em Geografia). 126f. Uberlândia: IG/UFU, 2013.

REN21. Renewable Energy Policy Network for the 21st Century. Renewables 2015 Global Status Report. REN21, 2015. Disponível em: <http://www.ren21.net>. Acesso em: junho/2016.

RUDORFF, B.F.T.; AGUIAR, D.A.; SILVA, W.F.; SUGAWARA, L.M.; ADAMI, M.; MOREIRA, M.A. Studies on the Rapid Expansion of Sugarcane for Ethanol Production in São Paulo State (Brazil) Using Landsat Data. Remote Sens, v. 2, p. 1057-1076, 2010.

SANTOS, H. F. Competitividade regional do setor sucroenergético na mesorregião Triângulo Mineiro/Alto Paranaíba: agricultura científica globalizada e implicações socioambientais no município de Uberaba - MG. Dissertação (Mestrado em Geografia). 281f. Campinas: IG/UNICAMP, 2017.

SANTOS, M. (2000) Por uma outra globalização: do pensamento único à consciência universal. 19 ed. Rio de Janeiro: Record, 2010. 
SANTOS, M. (1994) Técnica, espaço, tempo: globalização e meio técnicocientífico informacional. 5 ed. São Paulo: HUCITEC, 2008.

SIAMIG. Associação das Indústrias Sucroenergéticas de Minas Gerais. Portal da SIAMIG, 2016. Disponível em: <http://www.siamig.com.br>. Acesso em: julho/2016.

SILVEIRA, M. L. Território Usado: dinâmicas de especialização, dinâmicas de diversidade. Ciência Geográfica. Bauru, v. XV, n. 1, 4-12, jan./dez. 2011.

SPADOTTO, B. R. Centralização do capital e especialização territorial: o setor sucroenergético e o mercado de trabalho em Piracicaba (SP).

Dissertação (Mestrado em Geografia). 124f. Campinas: IG/UNICAMP, 2016.

SZMRECSÁNYI, T.; GONÇALVES, D. B. Efeitos Socioeconômicos e Ambientais da Expansão da Lavoura Canavieira no Brasil. In: XXVIII CONGRESSO DA ASSOCIAÇÃO DE ESTUDOS LATINO-AMERICANOS. Rio de Janeiro: LASA, 2009.

TEODORO, M. A. Concentração econômica do capital e especialização territorial produtiva no setor sucroenergético na região de Iturama (MG). Rio Claro: IGCE/UNESP, 2016.

THOMAZ JÚNIOR, A. Dinâmica Geográfica do Trabalho no Século XXI (Limites Explicativos, Autocrítica e Desafios Teóricos). Tese de Livre Docência. 941f. Presidente Prudente: FCT/UNESP, 2009.

UNICADATA. Dados da União da Industria de Cana-de-açúcar. Portal UNICA. 2017. Disponível em: <http://www.unicadata.com.br>. Acesso em: abril/2017.

UNICA. União da Industria de Cana-de-açúcar. A bioeletricidade da cana em números - Junho de 2016. Disponível em: <https://goo.gl/fQZzop>. Acesso em: junho/2016.

XAVIER, C. V. Análise sobre a concentração de terras na expansão da agroindústria canavieira: estudo de caso na região de Andradina.

Dissertação (Mestrado em Geografia). 177f. São Paulo: FFLECH/USP, 2012.

Estudos Geográficos, Rio Claro, 15(1): 106-132, jan./jun. 2017 (ISSN 1678-698X) 